\title{
Going the Distance: The Pros and Cons of Expanding Employees' Global Knowledge Reach
}

Shad S. Morris

Brigham Young University, morris@byu.edu

Follow this and additional works at: https://scholarsarchive.byu.edu/facpub

Part of the International Business Commons

\section{Original Publication Citation}

Morris, S.S., Zhong, B. and Makhija, M., 2015. Going the distance: The pros and cons of expanding employees' global knowledge reach. Journal of International Business Studies, 46(5), pp.552-573.

\section{BYU ScholarsArchive Citation}

Morris, Shad S., "Going the Distance: The Pros and Cons of Expanding Employees' Global Knowledge Reach" (2015). Faculty Publications. 2065.

https://scholarsarchive.byu.edu/facpub/2065

This Peer-Reviewed Article is brought to you for free and open access by BYU ScholarsArchive. It has been accepted for inclusion in Faculty Publications by an authorized administrator of BYU ScholarsArchive. For more information, please contact ellen_amatangelo@byu.edu. 


\title{
GOING THE DISTANCE: THE PROS AND CONS OF EXPANDING EMPLOYEES' \\ GLOBAL KNOWLEDGE REACH
}

\author{
Shad S. Morris \\ Marriott School of Management \\ Brigham Young University \\ 590 TNRB, Provo, UT 84602 \\ morris@byu.edu \\ Bijuan Zhong \\ Baruch College \\ City University of New York \\ Box 12-240, One Bernard Baruch Way, \\ New York, NY 1001 \\ Bi-Juan.Zhong@,baruch.cuny.edu \\ Mona Makhija \\ Fisher College of Business \\ The Ohio State University \\ 2100 Neil Avenue \\ Columbus $\mathrm{OH} 43220$ \\ makhija.2@osu.edu
}

Running Title: Expanding Employees’ Knowledge Reach

\begin{abstract}
About the Authors
Shad Morris ( $\mathrm{PhD}$, Cornell University) is the Georgia White Fellow and Associate Professor of Organizational Leadership and Strategy at the Marriott School of Management, Brigham Young University. Shad conducts research on international business and strategic human resource management, particularly focusing on how firms leverage their talent and social networks to globally innovate.
\end{abstract}

Bijuan Zhong (Ph.D. Ohio State University) is an Assistant Professor at Baruch College, City University of New York. Bijuan conducts research in the context of cross-border interactions and multinational enterprises, with a focus on social psychological processes. She is working on projects in the areas of knowledge management, multicultural human capital and innovation.

Mona Makhija (Ph.D. University of Wisconsin) is Professor of International Business at Fisher College of Business, The Ohio State University. Her research focuses on the effects of institutional features of national environments on the strategies of firms and behavior of managers, global strategies of multinational firms, and the effects of organizational control and coordination mechanisms on the management of knowledge. 


\begin{abstract}
While some scholars have suggested MNEs to be superior to markets for managing knowledge across geographically distant boundaries, how they actually accomplish this has not been fully considered. We address this void by developing and testing a model that highlights the critical role of organizational incentives in enhancing employees' internal search and use of knowledge. Data from 166 knowledgeintensive projects support our argument that, in contrast to process-based incentives that influence more local search, outcome-based incentives motivate employee teams to reach well beyond their immediate location, which in turn enhances performance. At the same time, we demonstrate that expanded reach also increases the likelihood of accessing more codifiable knowledge, which can hurt performance. Our model examines the contradictory — and previously unknown — effects of global knowledge reach.
\end{abstract}




\section{INTRODUCTION}

One primary advantage of the multinational enterprise (MNE) is that it provides a superior means for leveraging employees' experience and tacit knowledge across borders (e.g., Kogut \& Zander, 1993). According to such knowledge-based perspectives, the heterogeneous nature of knowledge from geographically dispersed locations increases the potential for finding unique and valuable insights to solve problems (Doz, Santos, \& Williamson, 2001). Both the search for and use of such geographically dispersed knowledge is referred to as "knowledge reach" (Sheremata, 2000). Knowledge-based perspectives make the implicit assumption that the MNE offers a unique social environment for employees to expand the distance and scope of their knowledge reach.

Yet, in reality MNEs' geographically dispersed knowledge is often not readily accessible to its employees. Seeking the most appropriate knowledge from within the far-flung, complex operations of MNEs can instead pose a significant challenge. The sheer effort involved in reaching out for knowledge from distant locations is greater than simply drawing on more proximately located knowledge, making employees reluctant to undertake the more difficult searches for knowledge in remote and dissimilar locations (Makela, Andersson, \& Seppala, 2012). For this reason, knowledge seekers naturally tend to minimize their reach (Andersson, Fersgren, \& Holm, 2002; Wittington, Owen-Smith, \& Powell, 2009), thus undermining the value of MNEs' dispersed knowledge. Hence, it is unclear what conditions prompt MNE employees to actually engage in potentially valuable yet challenging knowledge reach and the effects such behavior produces. The goal of this research is to address this void in the literature. Accordingly, the objectives of this research are to understand (a) the nature of incentives that motivate 
employees to reach for more distant knowledge from within the MNE and (b) the effects of knowledge reach on performance.

We expect that, similar to other organizational activities, employees' knowledge reach will be influenced by the nature of control and incentive systems in place (Andersson, Bjorkman, \& Forsgren, 2005; Taylor, Beechler, \& Napier, 1996). Incentive systems specify how employees are judged, evaluated, and rewarded in hopes of ensuring that organizational objectives are met. Researchers often classify such systems into two types: (1) "process-based incentives," which focus employees' attention on established processes or pre-specified behaviors for conducting their work, and (2) "outcome-based incentives," which focus employees' efforts on achieving pre-established outputs or standards (Ouchi \& Maguire, 1975; Ouchi, 1979; Sitkin \& Roth, 1993). We argue that, among knowledge seekers, outcome-based incentives will be more effective than process-based incentives in prompting employees to exert the necessary effort to achieve distant knowledge reach that directly enhances performance.

Nonetheless, we point out that the sheer complexity of knowledge reach can also lead to unintended consequences. Because of inherent difficulties in transferring "tacit" or intricate knowledge (Hansen, 1999; Song, Almeida, \& Wu, 2003; Szulanski, 1996), we expect that greater geographical reach will also increase the likelihood of employees procuring "codifiable" knowledge (i.e., knowledge that can be easily documented and conveyed across multiple media), which in turn reduces performance. Thus, we highlight a critical trade-off that MNEs face with respect to knowledge reach-positive performance results from accessing the valuable diversity of globally distant knowledge, along with negative performance results from accessing knowledge that is more codifiable in nature rather than more tacit forms of intricate knowledge. In doing so, our model highlights the critical role played by 
the nature of knowledge accessed via knowledge reach for performance. While codified knowledge may be easier to procure from distant locations, it is the more tacit forms of knowledge that enhance performance.

These arguments are the basis of our theoretical model. To test this model, we created a unique database of knowledge management activities associated with 166 internationally dispersed project teams within a large multinational professional services firm operating in 81 different countries. Focusing on project teams is appropriate here since this is the setting within which MNE employees make knowledge search decisions (Yu \& Zaheer, 2010).

By juxtaposing two different and rarely compared theoretical streams within the knowledgebased literature, our research bridges an important theoretical gap. One stream of thought addresses the inherent value of geographically dispersed knowledge in providing heterogeneity and potential value for MNEs (e.g., Kogut \& Zander, 1993), while the other stream stresses the inherent difficulties of integrating and transferring knowledge across geographic divides (Hansen \& Haas, 2001; Jensen \& Szulanski, 2004). Combining these theories allows us to highlight the challenges of employees' reaching for tacit knowledge that is geographically distant, including the problem that even appropriately incentivizing people to engage in knowledge reach does not ensure that they will access performance-enhancing tacit knowledge. The key insight from our study is that knowledge reach within the MNE is beneficial for performance due to the varied knowledge that can be drawn upon and potential for new insights that can be gained for problem solving. However, there are also pitfalls in the process of achieving this benefit. It is important for firms to recognize these pitfalls and actively 
enhance the likelihood of employees engaging in the more difficult processes of reaching for tacit knowledge.

\section{KNOWLEDGE REACH WITHIN MNES}

According to knowledge-based views (KBV) of the firm, varied or heterogeneous knowledge is key in determining superior firm performance (Conner \& Prahalad, 1996; Winter \& Szulanski, 2002). Heterogeneous knowledge includes "specialized competencies maintained by the individuals and groups that make up the organization" (Levinthal \& March, 1993: 103), all grounded in the firm's unique historical and social context. Such features render the firm's differentiated knowledge relatively immobile and difficult for competitors to imitate, thus constituting the basis for sustained competitive advantage (Barney, 1991; Nag \& Gioia, 2012). The firm's ongoing challenge is to encourage its employees to develop, deploy, and leverage these knowledge inventories in line with changing competitive conditions (Miller, 2002). The significant efforts required to develop suitable knowledge for such purposes serve to differentiate one firm from another. Since deploying and leveraging knowledge are predominantly social processes, researchers have highlighted the critical role of social capital in this regard (Morris \& Snell, 2011; Yli-Renko, Autio, \& Sapienza, 2001). A firm's ability to provide a social structure or community that facilitates internal knowledge reach is thus a fundamental element in enhancing its competitiveness over other firms (Kogut \& Zander, 1992).

Kogut and Zander (1993) extend this perspective to the MNE, particularly noting its ability to construct a multinational social structure for individuals and teams to discover and mobilize knowledge across borders that would be difficult to procure otherwise. Multidirectional knowledge flows within the MNE — between parent and foreign affiliates as well as between affiliates—is the key to its success 
(Luo \& Peng, 1999; Minbaeva, 2005; O’Donnell, 2000). These flows enable novel knowledge recombination, yielding insights that would otherwise remain locally embedded and fragmented. In this respect, accessing geographically distant knowledge is particularly valuable because it helps to reallocate resources more productively within the MNE (Moran \& Ghoshal, 1999: 395), and due to this, generate unique solutions to new problems (Hayek, 1945). Accessing such diverse knowledge addresses the inherent problem of resource immobility by allowing assets developed in one location to be applied in another. Hence, increasing knowledge reach promotes better knowledge leveraging across borders, leading to a competitive advantage (Reiche et al., 2009).

Despite the potential value of distant knowledge to decision makers within MNEs, leveraging such knowledge is costly (Berry, Guillen, \& Zhou, 2010). The very qualities that make globally dispersed knowledge worthwhile also impose important constraints in its procurement. Finding and applying geographically dispersed knowledge is much more complicated than finding and applying proximate knowledge (Cantwell, 2005; Joshi, Lazarova \& Liao, 2009; Kostova \& Roth, 2002). Such knowledge may have been developed under conditions that are ostensibly different from one situation to the next, making it difficult to understand how it can be extracted and applied in new contexts (Szulanski \& Jensen, 2006). Joshi, Labianca, and Caligiuri (2002: 278) argue that it is harder to urge teams to share knowledge if they are not in the same or nearby country because the physical distance between teams can induce a "lack of trust among members, breakdown of communication, and interpersonal conflict." Even when employees located across geographical boundaries know each other well, the intricacies involved in accessing global knowledge can reduce their interest in reaching out for it (Obstfeld, 2005). Levinthal and March (1993) link such challenges of knowledge search to 
bounded rationality, leading to "temporal myopia" (a focus on short-term rather than long-term solutions) and "spatial myopia" (a disinterest in knowledge available elsewhere in the firm).

As a result, employee groups have a natural predisposition to engage in local knowledge reach (Ambos \& Ambos, 2009; Gibson \& Zellmer-Bruhn, 2001; March \& Simon, 1958; Nelson \& Winter, 1982; Rosenkopf \& Nerkar, 2001). Local reach eases knowledge transfer because the people are very likely to frequently encounter one another face-to-face and thus better understand each other (cf., Allen, 1977). This may explain the evidence that increasing geographic distance among employees decreases the likelihood of their investing in cross-border relationships (Beugelsdijk \& Frijns, 2010; Disdier \& Head, 2008), thus reducing the probability that workers will seek knowledge or efficiencies from more distant locations (Beckerman, 1956; Kogut \& Singh, 1988). According to geographic propinquity (Krugman, 1991), individuals are naturally inclined to seek information from others in close proximity rather than those who are at a distance, limiting potential sources of "better advice" (Nebus, 2006). Consequently, extending employees' knowledge reach depends upon their willingness to move beyond local ideas and access ideas from distant locations (Ambos, Ambos, \& Schlegelmilch, 2006; Jensen \& Szulanski, 2004; Minbaeva, 2008). Evaluating how MNEs motivate knowledge reach among employees is therefore critical.

The KBV is generally silent regarding the specific mechanisms used to encourage knowledge reach among employees and their associated groups within a firm (Nag \& Gioia, 2012). Instead, the assumption is that employees' social structures automatically influence internal knowledge transfers (e.g., Kogut \& Zander, 1993: 625). While such social structures may indeed play a role here, it remains unclear what motivates employees to draw upon more distant social connections in their knowledge 
search (cf., Nebus, 2006). Given the difficulties associated with knowledge reach, we know little about how the firm accomplishes the internal search for and use of knowledge in ways that serve its specific interests. Researchers have suggested that the nature of employee incentives likely plays an important motivational role (Dyer \& Nobeoka, 2002; Gupta \& Govindarajan, 2000; Nickerson \& Zenger, 2004). However, research has yet to evaluate how MNE employees are incentivized to increase knowledge reach. Further research is also needed to understand how MNE employees accomplish knowledge reach and how the nature of the knowledge itself might differentially influence performance.

\section{CONCEPTUAL MODEL}

To address the voids in the literature noted above, in this section we develop a conceptual model (See Figure 2) that considers (1) the role of organizational incentive systems as antecedents to knowledge reach, and (2) both direct and indirect effects of this knowledge reach on performance. As noted by Turner and Makhija (2006), the organization's incentive systems are essential for motivating employees' knowledge management activities. The design of these incentive systems can be oriented towards reducing the costs and uncertainty of achieving specific organizational goals (Eisenhardt, 1985). We draw on this prior work to link incentives and knowledge reach within MNEs, arguing that employees' desire to expand their knowledge reach across geographical domains can be encouraged through appropriate incentives. Since knowledge reach can provide greater diversity of knowledge and afford superior problem-solving insights, our model suggests that knowledge reach will directly enhance performance. At the same time, the difficulty of transferring tacit knowledge across borders (e.g., Gupta \& Govindarajan, 2000; Hansen \& Haas, 2001) makes it essential to consider the nature of the knowledge that is being accessed to fully understand the implications of knowledge reach for 
performance. Thus, our model also suggests a relationship between knowledge reach and the codifiability of knowledge accessed from distant locations, which in turn affects performance. In this way, our model accounts for both direct and indirect effects of knowledge reach on performancereflecting a partial mediation model.

[Insert Figure 2 about here]

For two reasons, we focus on project teams rather than individual employees (Obstfeld, 2005; Orr \& Scott, 2008; Sheremata, 2000; Yu \& Zaheer, 2010). First, MNEs typically apply incentives to sets of employees, such as those within project teams, rather than to single employees. Second, knowledge search and problem solving activities are central activities for MNE project teams. ${ }^{1}$ In particular, innovation within MNEs typically emerges from team-level activity (Hitt, Bierman, Shimizu, \& Kochhar, 2001). Thus, a focus on project teams is more appropriate for developing the predictions of our model.

\section{Employee Incentives and Knowledge Reach}

Many researchers have emphasized that managerial approaches can be intentionally targeted toward managing knowledge flows among employees (Gant, Ichniowski, \& Shaw, 2002; Stroh \& Caligiuri, 1998). Employees' willingness to hunt for relevant knowledge outside their immediate domains hinges on where their incentives lie. To demonstrate this, we consider two main types of incentives: process-based incentives and outcome-based incentives (Makhija \& Stewart, 2002; Ouchi \& Macquire, 1975). Both process and outcome incentives prevail upon employees to behave in a manner consistent with the firm's goals and objectives (Anthony, 1965; Camillus, 1986). Process-based incentive systems evaluate and reward employees for following pre-established procedures and 
processes as closely as possible. Outcome-based incentives evaluate and reward employees for achieving pre-established objectives and specified goals. In a sense, process-based incentives focus on first-level objectives, while outcome-based incentives target second-level objectives (Nebus, 2006). Second-level objectives are the larger and more significant goals that are the final result of lower-level stages or objectives. In this respect, first-level objectives may be conceptualized as part of the progress toward a second-level objective (Vroom, 1995), and accomplished by obtaining the right information to move from one pre-identified stage to the next. On the other hand, second-level objectives may not have pre-established stages, and instead require employees to figure out on their own the best approaches for accomplishing them. In either case, however, meeting objectives requires the use of knowledge, making the type of incentive system used important for directing the requisite type of knowledge search behavior (Turner \& Makhija, 2006).

As noted above, process-based incentives prompt employees to follow pre-established behaviors and procedures to effectively accomplishing tasks. For example, many consulting firms might use a rule for a project team such as "before moving on to the project development stage, be sure to check with other similar projects." Because performance is evaluated in terms of how well this step (a first-level objective) is followed, rather than the overall project outcome (a second-level objective), the individual teams are more likely to complete this step in a more-or-less routine manner, choosing people to check with that are closest geographically, but not necessarily the best contextually (Nebus, 2006).

By providing more or less step-by-step directions, such incentives reflect high confidence on the part of the firm's managers regarding the best way to accomplish a project. Thus, this type of incentive is most appropriate when the best means for accomplishing the task are already known and 
when the requisite knowledge is close at hand. Employee teams following such a pre-established "script" will not need to look for diverse and complex knowledge beyond this framework in order to complete the task (Turner \& Makhija, 2006). If penalized for deviating from mandated processes, project teams are likely to maintain a narrow knowledge reach to readily available local contacts. It is for such reasons that Andersson et al. (2005) note that process-based controls tend to decrease the connectedness among subsidiary units and those outside their firm context. Importantly, process-based incentives help minimize unnecessary divergences in individual preferences among highly dispersed employees (Eisenhardt, 1985). Hence, process-based incentives (e.g., encouraging employees to go through proper channels and follow explicit procedures) are more relevant for economies of scale and scope in persuading employees to rapidly transfer prescribed knowledge from one location to another, but less beneficial in persuading employees to transcend local knowledge searches.

Some might argue that organizational units using process-based incentives may be able to overcome this inadequacy if they simply evaluate and reward employees for following the exact procedures for procuring distant knowledge. Note, however, that the responsibility falls on the manager for accurately specifying the correct processes. To do so managers would need to already know precisely where to find the most useful knowledge for the purposes of each project so that these steps can be exactly stipulated. It is, however, unlikely that managers can accurately predict where the most relevant knowledge exists within the MNE for completing a complex new project. An alternative approach could be to mandate procedures that cover all possible knowledge sources and solutions. This, of course, would be prohibitively time-consuming and expensive for the project team to try to 
accomplish. In light of these problems associated with the use of process incentives, we do not expect them to be effective in enhancing knowledge reach. Thus, we argue as follows:

Hypothesis 1a: The more process-based incentives are used, the less project teams will expand their knowledge reach within the MNE.

In contrast to process-based incentives, outcome-based incentives explicitly specify the required end results (i.e., second level objectives) rather than the means (i.e., first level objectives) through which they are to be achieved. Ultimately, employees are rewarded for their ability to achieve project goals instead of engaging in pre-established procedures as correctly as possible (Eisenhardt, 1985; Guthrie, 2007; Ouchi, 1979). Because such employees are allowed more freedom in how to achieve a desired outcome, they would be more inclined to look near and far for knowledge that might assist them. Kang, Morris, and Snell (2007) note that when knowledge workers are incentivized based on end results, they are more motivated to acquire a broader set of knowledge and skills and apply them to organizational operations. Outcome-related incentives may generate an organizational culture of "creative abrasion," in which employees are encouraged to constantly discover new and contextually different ideas and methods to improve productivity (Caligiuri, Lazarova, \& Zehetbauer, 2004). ${ }^{2}$

Since outcome-based incentives deemphasize any particular processes that must be followed in favor of specific outcomes that must be achieved, team members are allowed to do whatever they need to do to accomplish these outcomes. We expect, then, that under outcome-based incentives, project teams will draw on knowledge in more creative ways in order to achieve their goals. Since such incentives do not specify a particular approach or process for acquiring appropriate knowledge to complete a task, team members will have discretion regarding how they engage in this knowledge search. Outcome-based incentives provide the requisite motivation employees need to identify new and 
unique solutions for problems (Turner \& Makhija, 2006). If project teams feel they have greater accountability for failing to locate the relevant knowledge for a project's success, they will be more willing to amplify their knowledge search accordingly (Snell \& Youndt, 1995). Thus, we expect that the lack of emphasis on specified processes to be followed will enhance a team's desire to engage in extended geographical knowledge searches to uncover necessary knowledge:

Hypothesis 1b: The more outcome-based incentives are used, the more project teams will expand their knowledge reach within the MNE.

\section{Knowledge Reach and Performance}

An MNE's overall performance is based on the superior functioning of its subunits (Porter, 1986). In fact, knowledge search behaviors most responsible for overall firm performance reside at the team level within subunits (Doz, Santos, \& Williamson, 2001). Thus, improvements in local team performance will in turn enhance overall firm performance (Hansen \& Lovas, 2004). Within the same firm, employees in different geographic locations are likely to have faced a variety of problems and have developed approaches for solving them. These approaches may have important implications for solving problems elsewhere in the firm. Thus, teams can create value by pursuing new knowledge from myriad sources within the firm. This knowledge can help team members to gain a better understanding of how to most efficiently address the problems associated with their project, as well as enhance meaningful outcomes. When such employees expand their reach to include others in geographically distant locations, they increase their chances of finding relevant and valid information that can be used to improve their own solutions, as opposed to continually "reinventing the wheel," a time-consuming and costly approach. 
In addition to enhancing the likelihood of gaining knowledge relevant for their projects due to similar projects completed elsewhere in the firm, non-proximate knowledge also provides benefits due to its likelihood of being dissimilar to proximate knowledge. As noted by Henderson and Clark (1990), innovation comes about through the integration of diverse types of knowledge in unusual ways. Distant knowledge helps create knowledge diversity, facilitating new knowledge recombinations that yield novel insights (Galunic \& Rodan, 1998). In contrast, knowledge located nearby is more likely to already have connections to the team's existing knowledge due to similarity in environmental conditions and cultural influences, reducing its value in creating innovative new insights, approaches and solutions. Underscoring the importance of distant knowledge search in this regard, Myers and Marguis (1969) find that non-proximate knowledge sources account for roughly one-quarter of successful innovation. As a result, if a project team reaches across geographic boundaries within the organization, that team may be able to gather relevant knowledge that provides novel and better solutions to client problems (Amabile, 1988; Tversky \& Kahneman, 1973), and improve project performance within the firm (Björkman, Fey, \& Park, 2007). Thus, we posit the following: Hypothesis 2: The more employees expand their knowledge reach within the MNE, the higher their project performance.

\section{The Nature of Knowledge Reach and Performance}

We noted above that outcome-based incentives may have superior properties for expanding knowledge reach and boosting performance, but the type of knowledge actually reached may also correlate directly to performance. A key characteristic of knowledge is its level of codifiability, reflecting the ease in fully articulating and conveying all elements of the knowledge that affect its 
meaning (Polanyi, 1966). As Kogut and Zander (1992: 387) state: "Codifiabililty is a question of the degree that there exists an implied theory by which to identify and symbolically represent knowledge." The more codifiable the knowledge, the more clearly specified is the underlying theory through which its meaning can be derived. Less codifiable knowledge (i.e., tacit knowledge), on the other hand, has a less obvious "theory" that renders it less understandable. Tacit knowledge is more complex and difficult to deconstruct, indicating a "complicated understanding" of organizational and environmental processes that facilitates more precise outcomes (Nonaka, 1994). It is these features that make tacit knowledge important in creating firm-specific competencies that are difficult for competitors to imitate, and thus a fundamental reason for firms' superior performance (Conner \& Prahalad, 1996). Stressing the role of the firm as an integrator of knowledge, Grant (1996: 367) notes: "These criteria point to knowledge (tacit knowledge in particular) as the most strategically important resource which firms possess ..."

For the MNE as well, the primary driver of competitive advantage is knowledge that is less codifiable and more tacit in nature, making it unique and rendering it difficult to imitate or copy (Grant, 1996). Nonetheless, the very properties that make more tacit forms of knowledge valuable to the MNE also make that knowledge challenging to transfer and use across geographic distances within the MNE itself. Tacit knowledge is chiefly embedded in individuals and closely integrated within the firm's processes and systems (Zander \& Kogut, 1995), thus hindering the ability of others in different locations to recognize and draw on it. Since tacit knowledge is inherently difficult to convey in a complete form, transferring such knowledge typically requires employees to actively engage in its use over time, during which an appreciation for its complex interrelationships can slowly emerge (Polanyi, 1976). 
In contrast, more codifiable knowledge is easily transmitted and understood across geographical domains, which reduces search and use costs (Makhija \& Ganesh, 1997; Nonaka, 1994). According to Schulz (2003: 446), using codifiable knowledge allows project teams to "process new incoming knowledge faster because it facilitates and speeds up the establishment of linkages between old and new knowledge." An example of codifiable knowledge is a template from another project that enables employees to better understand and apply the knowledge relevant to their own project. Additionally, employees can query a database (a repository of codifiable knowledge) using multiple indexes and search functions to locate and retrieve existing knowledge. As Cantwell (2009) points out, information technology and templates have significantly decreased the costs of global knowledge reach. Moreover, Ambos and Ambos (2006) emphasize the efficiency of technology-based coordination compared to personal interactions across geographic distance.

While the marginal cost of searching for more codifiable knowledge decreases with distance (in conjunction with new developments in information and communication technology), the marginal cost of reaching for less codifiable (or more tacit) knowledge rises with distance (Audretsch, 1998; Beugelsdijk \& Cornet, 2002). The most effective way to uncover such knowledge may be through employees meeting in the same geographic space (Allen, 1977; Kogut, 1988). However, frequent meetings in one location may not be efficient due to the travel costs, language differences, and cultural barriers. Given the challenge of procuring tacit knowledge compared to codifiable knowledge across distances, we expect that a team's expanded reach will tend to elicit more codifiable forms of knowledge (Szulanski \& Jensen, 2006):

Hypothesis 3a: The more a project team extends its knowledge reach, the more it will draw upon codifiable, rather than tacit, forms of knowledge. 
As we noted earlier, knowledge-based theorists have stressed the role of asymmetries in knowledge in explaining performance differences among firms (Conner \& Prahalad, 1996). These asymmetries stem from the inability of competitors to imitate a firm's knowledge. As noted by Kogut and Zander (1992):

"Firms differ in their information and knowhow and these differences, when they are economically interesting, have persistent effects on relative performance . . . The persistence of differentials in firm performance lies in the joint problem of the difficulty of transferring and imitating knowledge.” (p. 387).

Knowledge that is difficult to imitate or transfer to other entities stems from its highly tacit nature (Grant, 1996; Polanyi, 1966). Such knowledge is complex and idiosyncratic to the firm, highly embedded in its systems or intricately woven into unique contexts in a way that reduces the ability to extract it meaningfully from these settings or convey the entirety of its substance. The difficulty in transferring tacit knowledge is a key reason for why knowledge-based scholars have stressed that it comprises the most valuable type of organizational knowledge for superior performance (Conner \& Prahalad, 1996; Kogut \& Zander, 1993). The indivisibility of tacit knowledge into meaningful components provides the MNE with sustainable advantages over competitors (Harzing, 2000; Kogut \& Zander, 1993) by enhancing inimitability of its knowledge and differentiation from competitors (e.g., Subramaniam \& Venkatraman, 2001). Indeed, Maskell and Malmberg (1999) point out that, as companies increase their international presence, tacit knowledge becomes more crucial in enhancing their competitive positions. They argue that the additional contextual elements associated with internationally distributed knowledge amplify the importance of less codifiable knowledge. Since less codifiable and more tacit knowledge embodies more valuable and unique concepts, and is the source of the firm's competitive 
advantage over other firms, we expect that less codifiable knowledge accessed through knowledge reach will increase project performance.

In contrast, codified knowledge does not offer the benefits of inimitability and uniqueness that enhance firms' competitive advantage. According to Szulanski and Jensen (2006), such knowledge does not provide deep causal explanations of the mechanisms by which knowledge can be successfully used. They argue that recipients of codified knowledge make adaptations to apply this knowledge to their own particular context, but these "presumptive adaptations of knowledge assets" actually removes the diagnostic value of the original practice and reduce performance (Szulanski \& Jensen, 2006: 937). By the same token, in examining the role of knowledge transfer in hospital settings, Edmondson et al. (2003) found that when surgical teams relied too much on the codified components of knowledge and not enough on the tacit elements of a new technology that was being implemented in their hospitals, it resulted in failure of the technology implementation. This study suggests that excessive reliance on codified knowledge reduces performance. Consistent with this, March (1991) found that codified knowledge drives out experimentation and the ability to address unique problems. This is particularly problematic for those operating across multiple countries (Rivkin, 2000).

This literature stresses that tacit knowledge has the specialized, idiosyncratic and intricate characteristics that enhance a firm's performance, while codified knowledge does not embody the deep and complex connections that make knowledge valuable for performance (Kogut \& Zander, 1996), and may actually embolden users to act presumptively on the knowledge they access (Szulanski \& Jensen, 2006). For these reasons, when employees access more codifiable knowledge through knowledge reach, this knowledge will reduce project performance. On the other hand, when employees access higher 
levels of less codifiable knowledge from other parts of the organization, it will improve project performance. In this way, the codifiability of accessed knowledge is expected to mediate the relationship between knowledge reach and project performance.

Hypothesis 3b: The more codifiable knowledge a project team draws upon, the lower its project performance.

\section{METHODS}

\section{Sample and Procedures}

Professional service firms, such as those in the law, consulting, accounting and healthcare industries, are highly reliant on knowledge management to accomplish their goals; thus, they provide a pertinent context for understanding how employees access knowledge to help deliver a product or service to a client (Zhang \& Li, 2010). Indeed, such firms are described as models for an increasingly knowledge-based economy (Empson, 2007; Gardner, Anand, \& Morris, 2008; Hinings \& Leblebici, 2003; Teece, 2003; Von Nordenflycht, 2010). Most professional services projects are bound to a particular geographic environment (Maister, 1993) and targeted to address a specific problem or set of problems faced by a client in that same location.

We collected data on consulting projects undertaken by a global professional services firmWorld Consult (a pseudonym). World Consult is a financial and management professional services firm that supplies fee-based technical assistance and consulting advice to private corporations, financial institutions, non-profit organizations, government agencies, and so on. World Consult operates in 139 total countries. Table 1 provides a list of those countries.

[Insert Table 1 about here] 
At World Consult, the project leaders who provide these services are typically located in the same countries as their clients. Nearly all the projects are specific to a client or clients in one country, with a few focused across countries but in one specific region. Some examples of project goals include helping a company (1) build capacity to operate on a larger scale, (2) increase market share over foreign competitors, (3) develop a financial plan for foreign direct investment, and (4) form a corporation more easily. The average project length is 36 months. The project leader has authority over how the project is accomplished and has a small support staff. Project teams are allowed to access any and all knowledge resources without a set process for accessing this knowledge. Consistent with the experience of other researchers (e.g., Orr \& Scott, 2008), project leaders serve as effective informants in describing their teams' experiences.

First, we conducted a large number of preliminary interviews with project leaders, support staff, and company managers within World Consult in order to understand the types of projects they were working on and the types of knowledge and incentives they were using. Our interviews confirmed prior research that project teams play a primary role in knowledge search and use within MNEs. Drawing upon existing measures whenever possible, we then developed a multiple-item survey to assess key constructs related to our hypotheses. The company's archival database allowed us to identify 668 nearly completed and recently completed projects (i.e., within two years). We then emailed the confidential surveys to the project leaders to obtain information on their team's knowledge search activities. In these surveys, project leaders were able to respond anonymously to questions relating to a specific project, whether recently completed or nearly completed. Since project leaders have primary authority over their projects, we considered their responses to be accurate assessments of the knowledge that was 
actually used during the project. To maintain confidentiality, the corporate office saw responses only in aggregated form. To motivate employees to complete the survey, we provided a final report for each country office to better understand where they stood in comparison to other offices within the firm. We also raffled prizes for those who participated in the survey.

We received responses from 186 leaders of 325 distinct local projects (a 49\% response rate). Since performance data is typically available 6-12 months after project completion, we were able to procure performance data for 166 projects.

\section{Dependent Variable}

Project performance. We utilized the company's own performance metrics to assess project performance. Consistent with our goal to connect knowledge search behaviors to project outcomes, this study's main strength is that these performance measures are rigorous, independent, and comparable evaluations across the firm. A semi-autonomous evaluation unit within World Consult visits the project site 6-12 months after project completion to obtain detailed data on project outcomes and client satisfaction. This unit makes great efforts to accurately capture performance, even administering surveys to clients in order to collect evidence on key performance indicators.

Prior to launching a project, project leaders identify promised deliverables and select measurable indicators unique to the project and its local context. Then the project leaders establish baselines and targets to ensure that the client's particular needs are satisfied. Once the team finishes the project, the evaluation unit conducts rigorous assessments to determine whether or not the project achieved its promised deliverables. For example, if the project promised to increase the capabilities of a client's employees in a particular unit, then the evaluation unit would assess the employees' new level 
of capabilities. In addition, the evaluators would conduct separate assessments to discover if the new capabilities led to increased worker performance.

Drawing on this information, our performance measure includes two separate constructs: (1) promised deliverables, the extent to which the solutions delivered to the client were consistent with what was originally promised, and (2) client impact, overall client performance assessed through changes in sales, profitability, and process efficiency. The rating unit from World Consult assigns the ratings for both of these measures after multiple reviews. After collecting all measures on promised deliverables, the rating unit assigns a rating. We took the measures from the ratings unit and averaged the two performance constructs into an overall 4-point scale. Since the cronbach alpha was 0.73 , we also combined the two constructs into one project performance variable.

\section{Independent Variables}

We administered a separate survey to project leaders in order to assess several independent variables. Each of the constructs below are based on a 5-point Likert scale ranging from 1 (strongly disagree) to 5 (strongly agree). For each respondent, we identified a specific project that he/she had actually led. Their responses related to that particular project. To reduce recall bias, project leaders were only asked to respond to their most recently completed projects.

Incentives. We evaluated two key types of organizational incentives identified in the literature: outcome-based and process-based incentives (Makhija \& Stewart, 2002; Snell, 1992; Turner \& Makhija, 2006). Project leaders report to country-level managers, who establish the project incentives. Project leaders responded to survey questions based on what types of incentives their country managers used for their project team. Because incentives were determined by country managers, project teams in 
different locations could receive different incentives. In fact, different project teams within the same country could receive different incentives, depending on the country manager's preferences. Due to this, the type of incentives was fairly varied.

We evaluated the presence of outcome-based controls through three items that linked knowledge type to financial outcomes, performance evaluation, and project goals. Conversely, we evaluated the presence of process-based controls through three items that linked the knowledge type to explicit procedures and procurement routines. ${ }^{3}$ We adapted these items from Makhija and Stewart (2002) to focus more closely on knowledge. Cronbach's alpha was 0.80 for the items related to outcome-based incentives and 0.85 for the items related to process-based incentives.

Knowledge reach. The knowledge reach construct reflects the relative geographical distance (i.e., how far employees have to search for information) and scope (i.e., how broad their search is) from which employees accessed internal knowledge. For this measure, we asked project leaders to consider a list of different locations within the MNE from which knowledge could be attained and to indicate "how much relevant knowledge/technical information" they had gathered from each location (from $1=$ very little to $5=\mathrm{a}$ large amount). ${ }^{4}$ Next, using the responses to these questions, we created an index to capture knowledge reach for each project (from $1=$ very close to $5=$ far away). We identified three knowledge source categories within the MNE: (1) within the country, (2) outside the country but within the same region, and (3) outside the region. With this information, we developed a "ring model" of proximity consistent with Beugelsdijk and Cornet (2002). The resulting ring model is depicted in Figure $1 .^{5}$ Note that these rings do not necessarily represent equal costs in distance, but they do reflect what are traditionally held as the primary geographic barriers to knowledge search (Shenkar, 2001). 
[Insert Figure 1 about here]

We first assigned varying weights to locations from which knowledge was sourced - the farther away the location, the higher the assigned weight. Specifically, we assigned a weight of 1 to locations within the country, a 10 to locations outside the country but within the same region, and a 100 to locations outside of the region. Next, we summed the weighted scores for all locations. Finally, we divided that by the total weight (i.e., 111) to standardize the sum. The final knowledge reach score ranges from 1 to 5 , with higher scores indicating higher knowledge reach. The calculation of knowledge reach is as follows:

$$
K R=\sum W_{i} Q_{i} / \sum W_{i}
$$

where $\mathrm{KR}$ is the index for knowledge reach, $\mathrm{Q}_{i}$ is the Likert scale on question $i$ for knowledge accessed in location $i ; \mathrm{W}_{i}$ is the weight given to knowledge accessed in location $i$.

Codifiability of knowledge accessed. We measured the codifiability of knowledge accessed for each project by adapting four items from Zander and Kogut (1995). They argue that measures for codifiable knowledge should capture "the extent to which the knowledge could be articulated in documents and software" (Zander \& Kogut, 1995: 81). Consistent with this definition, our survey asked the project leaders the extent to which the internal knowledge the team accessed was (1) easily put into document form; (2) aggregated for standardized use; (3) written in a manual describing how the activities are to be executed; and (4) easily taught to new staff in a training program. While high scores indicate more access to codifiable knowledge, lower scores reflect accessing more tacit knowledge. Cronbach's alpha for this construct was 0.93 .

\section{Control Variables}


International experience. We controlled for factors other than organizational incentives that may affect a project team's willingness to reach for distant knowledge. Such factors include the team's ability to perceive and embrace opportunities for increasing knowledge reach. For example, employees with little experience working in distant subunits may be unaware of different knowledge available in other locations. They may also be more reticent to access knowledge from these subunits, even when incentives are in place (Argote \& Ingram, 2000; Szulanski, 2000). In contrast, those with more international experience may have already established international networks (Minbaeva, Makela, \& Rabbiosi, 2012) that allow them to better locate and understand far-flung knowledge. To control for international experience, we calculated the number of countries in which each project leader has worked beyond six months.

Expatriate or local. Another factor affecting ability and opportunity with respect to knowledge reach may stem from whether or not the employee is a native or an expatriate in his or her home office. Native employees may have fewer opportunities to seek out more distant knowledge sources in comparison to their expatriate counterparts. And yet native employees may develop more specialized competence on local issues than their expatriate co-workers. However, because expats may have less localized knowledge, they might possess higher intrinsic motivation to search elsewhere for knowledge. Indeed, the inherently non-local nature of their connections may grant them greater skill for distant knowledge searches (Minbaeva, Makela, \& Rabbiosi, 2012). We utilized a dummy variable ( $1=$ expatriate, $0=$ non-expatriate) to account for whether or not the project leader is an expatriate or a native. 
Internal and external knowledge accessed. Since project leaders access knowledge not only within the firm (internal) but also that outside the firm (external) for accomplishing their goals, we have accounted for the possibility that such knowledge types are substitutable. To gauge the internal and external knowledge accessed, we used a multi-item measure that was developed and validated in prior research (Haas, 2006; Haas \& Hansen, 2007). We measured internal knowledge as the extent to which the teams accessed internal knowledge for their projects, while we measured external knowledge as the extent to which teams accessed external knowledge to accomplish projects. Cronbach's alphas were 0.79 for external knowledge accessed and 0.88 for internal knowledge accessed.

Codifiability of external knowledge. While we are particularly concerned with the codifiability of internal knowledge, we are also concerned with the codifiability of external knowledge, since this can influence how internal knowledge is accessed within the firm. We assessed this construct in a similar manner to the codifiability of internal knowledge construct, using four items from Zander and Kogut (1995). Cronbach's alpha was 0.91.

Project support staff. We accounted for the number of support staff for each project, since a larger support staff may collectively possess greater knowledge resources, which could enhance performance. However, a large staff may be more difficult to manage, which could hinder performance.

Knowledge accessed from headquarters. We also controlled for knowledge acquired from headquarters. By including this control variable, we can exclude any possibility that the quality of the knowledge from headquarters will influence the knowledge reach pattern within the MNE.

Region, industry, and country. Because projects are conducted within different countries, regions, and business lines, we conducted a robustness check to determine the potential impacts. We 
analyzed how the size of the country, region, and business line influence the size of their intra-class correlations (Skinner, Holt, \& Smith, 1989). This takes into account the degree of similarity within the same cluster (i.e., business line, country, and region). The larger the correlation, the more likely we are to provide subjective observations. This distortion from clustering is usually called "design effect." We tested for design effects of country, business line, and region on the dependent variables using a common formula in structural equation modeling: design effect $=1+(c-1) p$, where $\mathrm{c}$ is the average cluster size, and $p$ is the ICC (Cochran, 2007; Muthén and Satorra, 1995; Scott \& Holt, 1982; Skinner et al., 1997).

Approximate design effects under 2 mean that the variable is unlikely to impact the relationship(s) between the independent and dependent variables. As both Cheung and Au (2005) and Julian (2001) observe, when these correlation effects are below 2, conventional structural equation models present generally reasonable, unbiased results. Our analyses showed that design effects were only significant when we clustered performance by region. We therefore included region in our main model. By controlling for the region in which a project team operates, we were able to focus on projectlevel variables relevant to this paper and to control for potential region-oriented idiosyncrasies.

\section{RESULTS}

\section{Primary Analysis}

To test whether our final usable project data differed systematically from the project pool as a whole, we ran a logistic regression predicting the use of a project in our analysis based on controlled variables (project size, region, and project type). The chi-square test for all control variables has a pvalue of 0.17 , indicating that they have no predictive power either individually or collectively. A more 
serious concern is selection bias based on the outcomes of interest. If the probability of a project included in our models varies systematically with the dependent variable (i.e., performance), then selection bias may determine the relationships found between knowledge reach and performance. Hence, we reviewed all projects in the World Consult database that included performance data. Again using logistic regression, we assessed whether the performance measure could predict our usable sample. The chi-square test for all performance levels as dummy variables has a p-value of 0.13 , demonstrating that they have no predictive power individually or collectively. These tests rule out response bias and missing data bias.

Prior to testing our hypotheses, we used a confirmatory factor analysis (CFA) with maximum likelihood estimation to determine the reliability and fit of all key variables: the actual and project performance and the use of internal knowledge, external knowledge, outcome-based incentives, process-based incentives, codifiable internal knowledge, and codifiable external knowledge. We used AMOS to conduct the CFA, which suggested that the overall structure for all key variables is a good fit for the data $\left(\chi^{2}=105.26\right.$, d.f. $=56$; CFI $=0.98 ;$ RMSEA $\left.=0.05\right)$. All factor loadings were also significant $(p<0.001)$. We also assessed the key variables for composite reliability and convergent validity, the results showed good reliability and validity. See Table 2 for these results.

[Insert Table 2 here]

To assess the construct validity of process and outcome incentives, we ran nested CFA models. Overall, the best fitting CFA model includes both process incentives and outcome incentives as separate constructs within the model. In addition, a Chi-square difference test indicated that the model with the two incentives included separately was a significantly better fitting model than the one with the two 
included as one construct. ${ }^{6}$ We also tested our model using linear regression in Stata to determine the variance inflation factor (VIF) from using both outcome and process incentives to predict knowledge reach and project performance. When these regressions predict knowledge reach, the VIF scores are 2.19 and 2.22. When they predict project performance, the VIF scores are 2.27 and 2.18. Hence, all VIF scores are below the threshold of 5 that Studenmund (2001) recommends. Moreover, Table 3 reports the means, standard deviations, and correlations among the chosen variables.

[Insert Table 3 here]

We tested our hypotheses using structural equation modeling (SEM) (Godfrey \& Hill, 1995). Unlike multiple regression analysis, SEM has the unique ability to simultaneously examine a series of dependent relationships, such as when a dependent variable becomes an independent variable in subsequent relationships within the same analysis (Shook, Ketchen, Hult, \& Kacmar, 2004). We tested our SEM model in AMOS. The general hypothesized model fits the data reasonably well $\left(X^{2}=1232.59\right.$, d.f. $=511 ; \mathrm{CFI}=0.85 ; \mathrm{RMSEA}=0.04)$.

[Insert Table 4 and Figure 3 here]

Table 4 reports the testing of hypothesized relationships (see also Figure 2). Hypothesis 1a argued that greater use of process-based incentives would reduce the team's knowledge reach within the MNE because process controls tend to focus on first-order goals, thereby reducing incentives for employees to draw on less understood and more difficult processes for gaining knowledge. Our findings indicate that process-based incentives do reduce global knowledge reach $(\beta=-0.69, \mathrm{p}=0.03)$. Thus, Hypothesis 1a is supported. 
According to Hypothesis 1b, greater use of outcome-based incentives would boost the team's knowledge reach within the MNE because the freedom of focusing on outcomes, not processes better slows employees to search out necessary knowledge for achieving project goals. The results demonstrate that outcome-based incentives are, in fact, significantly related to expanded knowledge reach $(\beta=0.86, \mathrm{p}=0.02)$. Hence, Hypothesis $1 \mathrm{~b}$ is supported.

Hypothesis 2 suggested that, if teams engaged in distant knowledge reach, project performance would increase because, per the knowledge-based view of MNEs, subsidiaries can leverage superior endowments of heterogeneous valuable knowledge within the MNE into superior performance. Our findings also confirm this claim, showing a strong positive relationship between expanded knowledge reach and improved project performance $(\beta=0.08, \mathrm{p}<0.05)$. Hypothesis 2 is thus supported.

Hypothesis $3 \mathrm{a}$ contended that the more a project team extends its knowledge reach, the more likely it will draw upon codifiable rather than tacit knowledge because increasingly remote knowledge would be likewise increasingly challenging to locate, extract, and decipher. Thus, project teams would be more apt to draw upon more codifiable distant knowledge due to its relative simplicity. Indeed, our results also substantiate this, displaying a strongly significant relationship between expanded reach and more codifiable knowledge $(\beta=0.17, \mathrm{p}<0.05)$. Hypothesis $3 \mathrm{a}$ is therefore confirmed.

Finally, Hypothesis $3 \mathrm{~b}$ predicted that the more codifiable the knowledge reached, the lower project performance would be since codifiable knowledge, with less complexity and intrinsic insight, is not helpful for successful completion of projects. Our data supports this, indicating that more codifiability of knowledge leads to a decrease in project performance $(\beta=-0.18, \mathrm{p}<0.01)$. This suggests 
that expanding a team's knowledge reach will amplify performance as long as the knowledge itself is tacit in nature. Hypothesis $3 b$ is thus supported.

Since the model embodies a direct and an indirect effect between knowledge reach and project performance, we used bootstrapping to test the significance of both effects. Results suggest a partially mediated model (Preacher and Hays, 2004). The direct effect from knowledge reach to project performance is positive and significant $(\beta=0.04, p=0.05)$. The indirect effect from knowledge reach to project performance via access to codified knowledge is negative and significant at 0.1 level $(\beta=$ $-0.014, p=0.06)$. Both effects combined lead to a positive but insignificant $\operatorname{sign}(\beta=0.03$, s.d. $=0.02$, $p=$ n.s.), which supports the importance of distinguishing between these two effects. ${ }^{7}$

\section{Supplementary Analyses}

While our primary focus is global knowledge reach, cultural distance may have confounding effects on our measure. Cultural distance, not just physical distance, may influence the relationship between knowledge reach and project performance. Since culture establishes a lens through which knowledge is given meaning, it influences the assumptions underlying cause and effect (Kumar \& Nti, 1998), the interpretations of phenomena (Shenkar, 2001), and the relative importance of specific problems and issues (Hofstede, 1981). Consequently, cultural distance can reduce the understandability of the acquired knowledge, thereby impairing the ability of that knowledge to enhance performance.

Since not all countries covered in our database possess measured cultural dimensions, incorporating this variable into our main model greatly diminished our sample size. We therefore factored in the effect of cultural distance on project performance in a separate SEM analysis. We measure cultural distance from the country where the project was completed to the country where World 
Consult is headquartered. To cover a wider cultural perspective and to avoid some pitfalls of using Hofstede's (1980) cultural index measures, as discussed in Shenkar (2001), we developed a cultural index utilizing all nine dimensions from the GLOBE study (House, Hanges, Javidan, Dorfman, \& Gupta, 2004): assertiveness, institutional collectivism, in-group collectivism, future orientation, gender egalitarianism, humane orientation, performance orientation, power distance, and uncertainty avoidance. With Kogut and Singh's (1988) cultural distance index formulation, we created a separate index from and deviation along all nine GLOBE indices. ${ }^{8}$ We corrected for variation differences within each dimension and used the average. The cultural distance index of all nine dimensions did not significantly affect performance $(\beta=0.12$, n.s.). We also tested the effect of these dimensions individually (Barkema, Shenkar, Vermeulen, \& Bell, 1997). Only power distance significantly affected project performance $(\beta=0.06 ; p<0.05)$.

The results for our hypothesized relationships remained the same while the model fit was slightly worse $\left(X^{2}=1313\right.$, d.f. $=480 ; \mathrm{CFI}=0.83$; RMSEA $\left.=0.05\right)$. This may well be due to the fact that the cultural distance values are not available for all countries in our sample, substantially reducing the model's power. In all, however, controlling for cultural distance still yields results that support our argument regarding the antecedents and outcomes of global knowledge reach.

\section{DISCUSSION}

This research generally supports KBV theorists who have underscored the value of MNEs' distant knowledge in enhancing performance. A key insight from our model is that knowledge reach within the MNE is beneficial for performance due to the varied knowledge that can be drawn upon and potential for new insights that can be gained for problem solving. Nonetheless, we show that increasing 
employees' knowledge reach does not happen automatically within MNEs. Highlighting the inherent difficulties associated with knowledge reach, we noted that knowledge-based views of MNEs have neglected consideration of employees' willingness to engage in knowledge reach beyond their own specific locations and the problems of extracting the most meaningful knowledge form distant locations. Taking into account these considerations gives rise to dual paths between knowledge reach and performance, one reflecting a positive direct relationship between the two, and the other showing a negative indirect relationship in this regard.

Our theoretical model notes the importance of instituting appropriate control mechanisms that incentivize employees to engage in the arduous processes of knowledge reach, only after which can their performance increase. We argued that outcome-based systems provided the most appropriate incentives in this regard. The greater flexibility associated with outcome controls better incentivizes employees to expand knowledge reach more than inflexible process controls. Indeed, we found that outcome-based incentives expanded the teams' knowledge reach, while process-based incentives were seen to have a negative effect on knowledge reach. In doing so, this research sheds important light on the difficulties of achieving global knowledge reach within MNEs - it is not smoothly accomplished through preexisting internal social networks as the literature has assumed thus far (Kogut \& Zander, 1992).

At the same time, our analysis suggests an interesting paradox associated with knowledge reach. Once the appropriate incentives are instituted, expanded knowledge reach is indeed seen to directly enhance performance, as has been suggested by knowledge-based theorists. At the same time, we show how the difficulties in recognizing and extracting such distant knowledge also enhances the 
tendency of teams to draw upon knowledge that is more codifiable, which is detrimental to performance. In doing so, our findings call into question another key assumption in the literature - the idea that distant knowledge can always prove beneficial elsewhere in the firm. Characteristics of the knowledge itself can reduce effective knowledge transfer. Since valuable knowledge is often deeply embedded in its context or environment, extracting it in a meaningful way is difficult. The farther someone has to reach for knowledge, the more likely they will be to avoid the contextual complexities and access more codifiable knowledge in place of tacit knowledge. This research highlights the contradictory effects of distant knowledge on performance.

These findings offer several contributions to the KBV of MNEs. First, scholars have emphasized a need for deeper insights into the micro-foundations of firm-level strategies in order to understand the role individual actors play in knowledge activities enhance performance (Morris et al., 2014). They have expressed frustration with the "individual-less" state in much of the strategy literature, which presents little empirical data to show how individual- and team-level data influences higher-level performance. Our research addresses these limitations by considering processes associated with knowledge reach at a more micro level. Instead of assuming that managerial fiat ensures distant knowledge transfer among employees, we consider how outcome-based and process-based incentives influence a project team's knowledge sourcing and how these behaviors in turn influence the team's own performance. Our data regarding these relationships are unique to the literature.

Second, scholars espousing the KBV of firms have usually treated employees' willingness to reach for knowledge as a theoretical "black box" (cf., Foss \& Pedersen, 2004). However, not all organizations are equally effective at promoting knowledge reach (e.g., Gupta \& Govindarajan, 2001; 
Szulanski, 1996). Knowledge reach depends upon employees' inclination to search beyond their local context for new and worthwhile ideas, creating heterogeneous knowledge that can both heighten employee performance and the MNE's competitive advantage. Notably, we found that outcome-based incentives played an essential role in this regard, placing "within reach" those "things and forces" that are ultimately difficult to access (Schumpeter, 1934: 14). The type of knowledge searched not only influences the type of knowledge accessed, but also determines the amount of distance employees are willing to cover to potentially boost project performance. While greater knowledge reach may increase a team's chances of finding valuable knowledge to execute their project, it may also influence what kind of knowledge the employees find. If project teams are incentivized to span geographic barriers, they might, of course, access more codifiable and less tacit or socially complex knowledge to make this exchange less arduous. Hence, as we have found, expanded knowledge reach can yield tacit knowledge, which usually enhances performance, but it can also yield codifiable knowledge more frequently, which can decrease performance. These contradictory effects occur because the codification level of knowledge mediates the direct relationship between knowledge reach and performance (Rucker, Preacher, Tormala, \& Petty, 2011).

For the reasons noted above, the impact of amplified knowledge reach on performance should be positive due to the valuably diverse knowledge that employees access. However, expanding knowledge reach is difficult, especially as this knowledge becomes more environmentally embedded (or tacit) in nature. Thus, even when employees are motivated to extend their knowledge reach, they will tend to locate increasingly codifiable knowledge. Since codified knowledge tends to be problematic in producing a competitive advantage - a point that KBV scholars espouse-we (correctly) expect 
higher amounts of codifiable knowledge to reduce performance. Examining the effects of accessed codifiable knowledge has theoretical and practical importance in helping us comprehend the pros and cons of increased knowledge reach.

In sum, while KBV researchers have underscored the value of knowledge reach in enhancing performance within the MNE, they have not adequately considered (a) the importance of incentivizing employees to expand their knowledge reach, and (b) the inherent difficulty of accessing distantly located tacit knowledge. Our research illuminates these significant but overlooked elements. Incorporating both of these elements allowed us to showcase two alternative paths by which knowledge reach influences performance.

\section{IMPLICATIONS FOR FUTURE RESEARCH}

Our research suggests several new directions for future work. While our model shows that knowledge reach within the MNE is beneficial for performance due to the varied knowledge that can be drawn upon and potential for new insights that can be gained for problem solving, there are also pitfalls in the process of achieving this benefit. The model highlights the need for managers to be cognizant of the inherent difficulties in achieving effective knowledge reach and manage employees and teams appropriately. However, it is possible that there is an optimal level of knowledge reach under which the benefits are automatically maximized and negative effects minimized. There could be tradeoffs in this regard - while lower levels of knowledge reach may improve the likelihood of this knowledge being tacit (with less effort devoted to knowledge reach and more devoted to extracting tacit knowledge), the benefits of knowledge reach are reduced in this scenario. By the same token, higher 
levels of knowledge reach emphasized would reduce ability to focus on tacit knowledge. Future research could consider these possible tradeoffs in greater depth. Such an investigation may uncover an optimal level of knowledge reach, beyond which the firm in unable to effectively employ the knowledge accessed. It may also suggest that there is an optimal level of tacit knowledge that can be gained through knowledge reach. In this regard, it may be that the most tacit forms of knowledge are inaccessible through knowledge reach, and that inefficiencies arise from accessing such high levels of such knowledge. On the other hand, research may show that the costs of procuring such highly tacit knowledge are well worth it for enhancing performance.

While we focused on MNEs' internal knowledge, other scholars have noted that knowledge both inside and outside the firm's boundaries can improve MNE performance (Bartlett \& Ghoshal, 1989; Prahalad \& Doz, 1999). Although we controlled for the effects of external knowledge in our analysis, future research should investigate further how MNEs effectively source and use external knowledge. For example, external knowledge may be more difficult to identify and integrate than internal knowledge because external knowledge can reside virtually anywhere. Identifying appropriate external knowledge may prove a riskier undertaking than identifying internal knowledge. It would be useful to know, therefore, how employee incentives influence them to search out this type of knowledge. Additional research could investigate the interactions between external and internal knowledge searches, explaining, for example, the extent to which they substitute for or complement each other. Can large MNEs, with greater internal knowledge resources, rely less on external knowledge sources than smaller MNEs can? How do incentives for accessing external and internal knowledge differ? 
The contradictory relationship highlighted here between knowledge reach and performance also deserves further consideration. True, outcome incentives encourage employees to undertake the challenging processes associated with global knowledge reach. However, if such reach results in accessing more codifiable knowledge, the employees' efforts will be stifled since codified knowledge is not typically a source of competitive advantage (Barney, 1986). A closer analysis of organizational incentives may explain how organizations ensure that the acquired knowledge is in fact tacit and thus more valuable. It is possible that an MNE designs specific incentives to accomplish the joint goals of knowledge reach and accessing more tacit knowledge. For example, it may motivate employees through outcome-based incentives that encourage them to search for knowledge in distant locations, but also encourage more personal forms of interaction, deep dives, and high-involvement techniques to make sure the knowledge they do access is tacit in nature. Other ways of ensuring access to tacit knowledge may stem from greater use of rotation programs, budgets for travel to visit with colleagues and view others' project sites, and ratings of employees based on the time and effort spent in working directly with colleagues in distant locations. In addition, training and other mechanisms may be used that improve employees' skills for recognizing, extracting and utilizing tacit knowledge.

Future research should also consider how structuring of teams and ensuring diversified team capabilities can also play a role in enhancing tacit knowledge reach. The difficulties in achieving both more knowledge reach and greater accessing of tacit knowledge may be mitigated by individual members being given responsibility for only limited areas to search for knowledge, or those locations to which they have increased access or familiarity. Since members are able to gain detailed understanding of specific locations in this way, their ability of extract codified knowledge from those 
locations would go up. The team members can then pool their individual knowledge reach efforts, which would then increase the overall level of knowledge reach as well as the extent of tacit knowledge accessed. In general, such approaches for enhancing employees' sensitivities to the unique characteristics of tacit knowledge and their appreciation for how these influence favorable project outcomes can be accomplished via additional investments in employees. While such incentives may appear to be costly to the firm, based on our findings, such costs will pay off in terms of increased ability of employees to contribute to the MNE's bottom line.

This research also offers several practical implications. Our research can help managers navigate the contradictions inherent in the relationship between knowledge reach and performance. Since increased knowledge reach can be both helpful and harmful, managers should urge employees to expand their knowledge reach, but to do so while monitoring how much codified versus tacit knowledge their employees are drawing upon, especially if the nature of the project itself is highly complex and tacit in nature. Many companies involved in highly complex knowledge work engage in significant initiatives to codify their workers' knowledge and their projects to ensure that the knowledge is easily accessible to others. Such efforts are important and necessary, especially within the MNE, but they must be tempered with a sensitivity to the importance of tacit or "uncodifiable" knowledge. For example, rather than trying to decrease the level of knowledge codification, managers might want to focus on codification efforts that urge people to personally connect and interact with knowledge providers. Such efforts may be prompted by referral systems or other codifiable forms that can foster a more personal narrative (Morris \& Oldroyd, 2009). 
Ultimately, employing a combination of both process and outcome controls to incentivize teams may be the most effective. Managers should therefore find ways to proactively manage the natural inclination of employees to increase the amount of codifiable knowledge they draw upon as they increase their knowledge reach. For example, firms might manage this tension by balancing process issues related to the need to access more tacit and rich forms of knowledge while still rewarding outcomes. ${ }^{9}$ A company may effectively motivate employees through outcome-based incentives that encourage them to search for knowledge wherever they want, but to use personal interactions, deep dives, and other tacit sources, thus helping them focus on first-order goals so that the knowledge they actually access is tacit in nature. Such nature-of-knowledge incentives may encourage employees to more readily use budgets for travel to visit with colleagues, join cross-border communities of practice, and call distant peers to follow-up on codified documents. While such incentives may seem costly to the firm, we expect such costs will pay off in terms of increasing employees' capacity to not only do the right thing, but to do it in the right way. 


\section{NOTES}

${ }^{1}$ Similarly, scholars have increasingly argued that local teams, rather than an individual or subsidiary, are the primary source of heterogeneous knowledge within MNEs (Doz, Santos, \& Williams, 2001; Hansen \& Lovas, 2004; Laurie, Doz, \& Sheer, 2006). Such teams must search for knowledge relevant to their tasks or goals (Zellmur-Bruhn \& Gibson, 2006).

${ }^{2}$ Note that outcome-based incentives can also be detrimental when processes must be followed. For example, if the specified end result is maximizing shareholder value, then a company may engage (as did Enron) in questionable processes that result in short-term benefits but long-term harm to the company and its clients.

${ }^{3}$ Items assessing outcome incentives included (1) "financial incentives were tied to the effective use of knowledge"; (2) "performance evaluations took into account the effective use of knowledge"; and (3) "we were encouraged to use new ways to obtain knowledge." Items assessing process incentives included (1) "there were explicit procedures for obtaining this knowledge"; (2) "it was important go through channels to get this knowledge"; and (3) "we knew in advance how long it would take to procure this knowledge."

${ }^{4}$ The list of different knowledge sources within the MNE included four categories: (1) headquarters (e.g., business line manager, headquarter experts), (2) your facility within the country (e.g., general manager, office colleagues), (3) facilities outside the country but within the region (e.g., regional business line specialist), and (4) facilities outside your region (e.g., a colleague who has done similar work).

${ }^{5}$ The ring model is an approximation of geographical distance. Since countries and regions vary in geographic distance, the ring system is not as symmetrical as Figure 1 suggests. As an example of how we calculated knowledge reach, consider a project in India. The knowledge level accessed from within India is 3, from outside the country but within Asia is 4, and from outside of Asia is 5. Thus, knowledge reach is assessed as $(1 * 3+10 * 4+100 * 5) / 111$ or 4.89 . This approach is consistent with Beugelsdijk and Cornet (2002). Notably, the knowledge reach measure is robust for different weights assigned to knowledge locations, producing the same results for different weights.

${ }^{6} \mathrm{We}$ used a simple Chi-square difference test to compare our model in which process and outcome incentives are entered as separate variables (Chi-square $=105.26$; d.f. $=56$; $\mathrm{CFI}=0.98, \mathrm{RMSEA}=0.05$ ) with an identifiable nested model in which the process and outcome variables are combined as one variable (Chi-square $=142.63$; d.f. $=$ 57 ; CFI $=0.96$, RMSEA $=0.06$ ). The Chi-square difference test shows that our model is significantly better than this alternative model (chi-square difference $=37.37$; d.f. $=1 ; p<0.05$ ).

${ }^{7}$ Since the model also possesses a mediated path relationship between incentives and performance, we separately examined the indirect effects implicit within the model using a separate analysis. While the indirect effect from outcome based incentives to project performance via knowledge reach is significant $(p<0.05)$, the direct effect from outcome based incentives to project performance is not significant. Neither the indirect effect from process based incentives to project performance via knowledge reach nor the direct effect from process based incentives 
to project performance are significant. The indirect effect from knowledge reach to project performance via codified knowledge is negative in sign and significant at the .1 level $(p=0.06)$. The direct effect from knowledge reach to project performance is also significant $(p<0.05)$.

${ }^{8}$ For the GLOBE measures, we used the "as is" scores, not the "should be scores" because, given our focus on behaviors, actual practices are more pertinent to this study.

${ }^{9}$ We would like to thank an anonymous reviewer for this idea. 


\section{REFERENCES}

Allen, T. J. 1977. Managing the flow of technology. Cambridge, MA: MIT Press.

Amabile, T. M. 1988. A model of creativity and innovation in organizations. In B. M. Staw \& L. L. Cummings (Eds.), Research in Organizational Behavior (Vol. 10): 123-167. Greenwich, CT: JAI Press.

Ambos, T. C., \& Ambos, B. 2009. The impact of distance on knowledge transfer effectiveness in multinational corporations. Journal of International Management, 15(1): 1-14.

Ambos, T. C., Ambos, B., \& Schlegelmilch, B. B. 2006. Learning from foreign subsidiaries: An empirical investigation of headquarters' benefits from reverse knowledge transfers. International Business Review, 15(3): 294-312.

Andersson, U., Björkman, I., \& Forsgren, M. 2005. Managing subsidiary knowledge creation: The effect of control mechanisms on subsidiary local embeddedness. International Business Review, 14(5): 521-538.

Andersson, U., Forsgren, M. \& Holm, U. 2002. The strategic impact of external networks: Subsidiary performance and competence development in the multinational corporation. Strategic Management Journal, 23(10): 979-996.

Anthony, R. N. 1965. Planning and control systems: A framework for analysis. Boston, MA: Harvard Business School Publisher.

Argote, L., \& Ingram, P. 2000. Knowledge transfer: A basis for competitive advantage in firms. Organizational Behavior and Human Decision Processes, 82(1): 150-169.

Ariely, D., Bracha, A., \& Meier, S. 2009. Doing good or doing well? Image motivation and monetary incentives in behaving prosocially. American Economic Review, 99(1), 544 555.

Audretsch, B. 1998. Agglomeration and location of innovative activity. Oxford Review of Economic Policy, 14(2): 18-29. 
Bagozzi, R.P. \& Yi, Y. 1990. Assessing Method Variance in Multitrait-Multimethod Matrices: The Case of Self-Reported Affect and Perceptions at Work, Journal of Applied Psychology, 75: 547-560.

Barkema, H. G., Shenkar, O., Vermeulen, F., \& Bell, J. H. 1997. Working abroad, working with others: How firms learn to operate international joint ventures. Academy of Management Journal, 40(2), 426-442.

Barney, J. B. 1986. Organizational culture: Can it be a source of sustained competitive advantage? Academy of Management Review, 11(3), 656-665.

Barney, J. B. 1991. Firm resources and sustained competitive advantage. Journal of Management, 17(1): 99-120.

Bartlett, C. A., \& Ghoshal, S. 1989. Managing across borders: The transnational solution. London: Random House.

Beckerman, W. 1956. Distance and the pattern of intra-European trade. Review of Economics and Statistics, 38(1): 31-40.

Berry, H., Guillén, M. F., \& Zhou, N. 2010. An institutional approach to cross-national distance. Journal of International Business Studies, 41(9), 1460-1480.

Beugelskijk, S., \& Cornet, M. 2002. "A far friend is worth more than a good neighbor": Proximity and innovation in a small country. Journal of Management and Governance, 6(2): $169-188$.

Beugelskijk, S., \& Frijns, B. 2010. A cultural explanation of the foreign bias in international asset allocation. Journal of Banking and Finance, 34(9): 2121-2131.

Björkman, I., Fey, C. F., \& Park, H. J. 2007. Institutional theory and MNC subsidiary HRM practices: Evidence from a three-country study. Journal of International Business Studies, 38(3): 430-446. 
Caligiuri, P., Lazarova, M., \& Zehetbauer, S. 2004. Top managers' national diversity and boundary spanning: Attitudinal indicators of a firm's internationalization. Journal of Management Development, 23(9): 848-859.

Camillus, J. C. 1986. Strategic planning and management control: Systems for survival and success. New York: Lexington Books.

Cantwell, J. A. 2005. MNE competence-creating subsidiary mandates. Strategic Management Journal, 26(12): 1109-1128.

Cantwell, J. A. 2009. Location and the multinational enterprise. Journal of International Business Studies, 40 (1): 35-41.

Cheung, W. L., \& Au, K. 2005. Applications of multilevel structural equation modeling to crosscultural research. Structural Equation Modeling, 12(4): 598-619.

Cochran, W. G. 2007. Sampling techniques. New York: John Wiley \& Sons.

Conner, K. R., \& Prahalad, C. K. 1996. A resource-based theory of the firm: Knowledge versus opportunism. Organization Science, 7(5): 477-501.

Disdier, A. C., \& Head, K. 2008. The puzzling persistence of the distance effect on bilateral trade. Review of Economics and Statistics, 90(1): 37-48.

Doz, Y. L., Santos, J. F. P., Williamson, P. 2001. From global to metanational: How companies win in the knowledge economy. Boston: Harvard Business School Press.

Dyer, J. H., \& Nobeoka, K. 2002. Creating and managing a high performance knowledge-sharing network: The Toyota case. Strategic Management Journal, 21(3), 345-367.

Edmondson, A. C., Winslow, A. B., Bohmer, R. M., \& Pisano, G. P. (2003). Learning how and learning what: Effects of tacit and codified knowledge on performance improvement following technology adoption. Decision Sciences,34(2), 197-224.

Eisenhardt, K. M. 1985. Control: Organizational and economic approaches. Management Science, 31(2): 134-149. 
Empson, L. 2007. Managing the modern law firm: New challenges, new perspectives. New York: Oxford University Press.

Foss, N. J. and Pedersen, T. 2004. Organizing knowledge processes in the multinational corporation: An introduction. Journal of International Business Studies, 35(5): 340-349.

Galunic D. Charles., \& Simon Rodan. 1998. Resource recombinations in the firm: Knowledge structures and the potential for Schumpeterian innovation. Strategic Management Journal, 19(12): pp. 1193-1201.

Gant, J., Ichniowski, C., \& Shaw, K. 2002. Social capital and organizational change in highinvolvement and traditional work organizations. Journal of Economics and Management Strategy, 11(2): 289-328.

Gardner, H. K., Anand, N., \& Morris, T. 2008. Chartering new territory: Diversification, legitimacy, and practice area creation in professional service firms. Journal of Organizational Behavior, 29(8): 1101-1121.

Gibson, C. B., \& Zellmer-Bruhn, M. E. 2001. Metaphors and meaning: An intercultural analysis of the concept of teamwork. Administrative Science Quarterly, 46(2): 274-303.

Godfrey, P. \& Hill, C. 1995. The problem of unobservables in strategic management research. Strategic Management Journal. 16(7): 519-533.

Grant, R. M. (1996). Toward a Knowledge-Based Theory of the firm. Strategic Management Journal, 17(S2), 109-122.

Gregersen, H. B., Mendenhall, M. E., \& Stroh, L. K. 1999. Globalizing people through international assignments. Reading, MA: Addison-Wesley.

Gupta, A. K., \& Govindarajan, V. 2000. Knowledge flows within multinational corporations. Strategic Management Journal, 21(4), 473-496.

Gupta, A. K., \& Govindarajan, V. 2001. Converting global presence into global competitive advantage. Academy of Management Executive. 15(2): 45-58. 
Guthrie, J. P. 2007. Remuneration: Pay effects at work. In P. Boxall, J. Purcell, \& P. Wright, (Eds.), The handbook of human resource management. Oxford: Oxford University Press, 344- 363.

Haas, M. R. 2006. Acquiring and applying knowledge in transnational teams: The roles of cosmopolitans and locals. Organization Science, 17(3): 367-384.

Haas, M. R., \& Hansen, M. T. 2007. Different knowledge, different benefits: toward a productivity perspective on knowledge sharing in organizations. Strategic Management Journal, 28(11): 1133-1153.

Hair, J. F., Anderson, R. E., Tatham, R. L., \& William, C. (1998). Black (1998), Multivariate data analysis.

Hansen, B. E. 1999. Threshold effects in non-dynamic panels: Estimation, testing, and inference. Journal of Econometrics, 93(2), 345-368.

Hansen, M. T., \& Haas, M. R. 2001. Competing for attention in knowledge markets: Electronic document dissemination in a management consulting company. Administrative Science Quarterly, 46(1), 1-28.

Hansen, M. T., \& Lovas, B. 2004. How do multinational companies leverage technological competencies? Moving from single to interdependent explanations. Strategic Management Journal, 25(8-9): 801-822.

Harzing, A. W. 2000. An empirical analysis and extension of the Bartlett and Ghoshal typology of multinational corporations. Journal of International Business Studies, 31(1): 101-120.

Hayek, F. A. 1945. The use of knowledge in society. American Economic Review, 35(4): 519530.

Henderson, R., \& K. Clark .1990. Architectural innovation: The reconfiguration of existing product technologies and the failure of established firms. Administrative Science Quarterly, 35, pp. 930. 
Hinings, C.R., \& Leblebici, H. 2003. Editorial introduction to the special issue: Knowledge and professional organizations. Organization Studies, 24(6): 827-830.

Hitt, M. A., Biermant, L., Shimizu, K., \& Kochhar, R. 2001. Direct and moderating effects of human capital on strategy and performance in professional service firms: A resourcebased perspective. Academy of Management Journal, 44(1): 13-28.

Hocking, J. B., Brown, M. and Harzing, A.-W. 2007. Balancing global and local strategic contexts: Expatriate knowledge transfer, applications, and learning within a transnational organization. Human Resource Management, 46(4): 513-533

Hofstede, G. 1980. Culture's consequences: International differences in work related values. Berkeley Hills, CA: Sage Publishing.

Hofstede, G. 1981. Management control of public and not-for-profit activities. Accounting, Organizations and Society, 6(3), 193-211.

House, R. J., Hanges, P. J., Javidan, M., Dorfman, P. W., \& Gupta, V. 2004. Leadership, culture, and organizations: The GLOBE study of 62 societies. Thousand Oaks, CA: Sage Publications.

Jensen, R., \& Szulanski, G. 2004. Stickiness and the adaptation of organizational practices in cross-border knowledge transfers. Journal of International Business Studies, 35(6): 508523.

Joshi, A., Labianca, G., \& Caligiuri, P. M. 2002. Getting along long distance: Understanding conflict in a multinational team through network analysis. Journal of World Business, 37(4): $277-284$.

Joshi, A., Lazarova, M. B., \& Liao, H. 2009. Getting everyone on board: The role of inspirational leadership in geographically dispersed teams. Organization Science, 20(1): 240-252.

Julian, M. W. 2001. The consequences of ignoring multilevel data structures in nonhierarchical covariance modeling. Structural Equation Modeling, 8(3): 325-352. 
Kang, S. K., Morris, S. S., \& Snell, S. A. 2007. Relational archetypes, organizational learning, and value creation: Extending the human resource architecture. Academy of Management Review, 32(1): 236-256.

Kogut, B. 1988. Joint ventures: Theoretical and empirical perspectives. Strategic Management Journal, 9(4): 319-332.

Kogut, B., \& Singh, H. 1988. The effect of national culture on the choice of entry mode. Journal of International Business Studies, 19(3): 411-432.

Kogut, B., \& Zander, U. 1992. Knowledge of the firm, combinative capabilities, and the replication of technology. Organization Science, 3(3): 383-397.

Kogut, B., \& Zander, U. 1993. Knowledge of the firm and the evolutionary theory of the multinational corporation. Journal of International Business Studies, 24(4): 625-645.

Kostova, T., \& Roth, K. 2002. Adoption of an organizational practice by subsidiaries of multinational corporations: Institutional and relational effects. Academy of Management Journal, 45(1): 215-233.

Krugman, P. R. 1991. Geography and trade. Cambridge, MA: MIT Press.

Kumar, R., \& Nti, K. O. 1998. Differential learning and interaction in alliance dynamics: A process and outcome discrepancy model. Organization Science, 9(3), 356-367.

Laurie, D. L., Doz, Y. L., \& Sheer, C. P. (2006). Creating new growth platforms. Harvard Business Review, 84(5), 80.

Lazarova, M., \& Tarique, I. 2005. Knowledge transfer upon repatriation. Journal of World Business, 40(4), 361-373.

Levinthal, D. A., \& March, J. G. 1993. The myopia of learning. Strategic Management Journal, 14(S2): 95-112.

Luo, Y., \& Peng, M. W. 1999. Learning to compete in a transition economy: Experience, environment, and performance. Journal of International Business Studies: 269-295. 
Maister, D. 1993. Managing the professional service firm. New York: Free Press Paperbacks.

Mäkelä, K., Andersson, U., \& Seppälä, T. 2012. Interpersonal similarity and knowledge sharing within multinational organizations. International Business Review, 21(3): 439-451.

Makhija M. V., \& Ganesh, U. 1997. The relationship between control and partner learning in learning-related joint ventures. Organization Science, 8(5): 508-527.

Makhija, M. V., \& Stewart, A. C. 2002. The effect of national context on perceptions of risk: A comparison of planned versus free-market managers. Journal of International Business Studies: $737-756$.

March, J. G., \& Simon, H. A. 1958. Organizations. New York: John Wiley \& Sons.

Maskell, P., \& Malmberg, A. 1999. The competitiveness of firms and regions. European Urban and Regional Studies, 6(1): 9.

Miller, K. 2002. Knowledge inventories and managerial myopia. Strategic Management Journal. 23(8): 689-706.

Minbaeva, D. B. 2005. HRM practices and MNC knowledge transfer. Personnel Review, 34(1): $125-144$.

Minbaeva, D. 2008. HRM Practices affecting extrinsic and intrinsic motivation of knowledge receivers and their effect on the intra-MNC knowledge transfer. International Business Review, 17(6): 703-713.

Minbaeva, D., Mäkelä, K. \& Rabbiosi, L. 2012. Linking HRM and knowledge transfer via individual-level mechanisms. Human Resource Management, 51(3): 387-405.

Moran, P., \& Ghoshal, S. 1999. Markets, firms, and the process of economic development. Academy of Management Review, 24(3): 390-412.

Morris, S. S., \& Oldroyd, J. B. 2009. To boost knowledge transfer, tell me a story. Harvard Business Review, 87(5): 23-24. 
Morris, S. S., Hammond, R. A., \& Snell, S. A. 2014. A microfoundations approach to transnational capabilities: The role of knowledge search in an ever-changing world. Journal of International Business Studies, 45(4): 405-427.

Morris, S. S., \& Snell, S. A. 2011. Intellectual capital configurations and organizational capability: An empirical examination of human resource subunits in the multinational enterprise. Journal of International Business Studies, 42(6): 805-827.

Muthén, B. O., \& Satorra, A. 1995. Technical aspects of Muthén's LISCOMP approach to estimation of latent variable relations with a comprehensive measurement model. Psychometrika, 60(4): 489-503.

Myers, S., \& Marquis, D. G. 1969. Successful industrial innovations. A study of factors underlying innovation in selected firms. Washington, D.C.: National Science Foundation.

Nag, R., \& Gioia, D. A. 2012. From common to uncommon knowledge: Foundations of firmspecific use of knowledge as a resource. Academy of Management Journal, 55(2): 421457.

Nebus, J. 2006. Building collegial information networks: A theory of advice network generation. Academy of Management Review, 31(3): 615-637.

Nelson, R. R., \& Winter, S. 1982. An evolutionary theory of economic change. Cambridge, MA: Harvard University Press.

Nickerson J., \& Zenger, T. 2004. A knowledge-based theory of the firm: The problem-solving perspective. Organization Science, 15(6): 617-632.

Nonaka, I. 1994. A dynamic theory of organizational knowledge creation. Organizational Science, 5(1):14-37.

Obstfeld, D. 2005. Social networks, the tertius iungens orientation, and involvement in innovation. Administrative Science Quarterly, 50(1): 100-130. 
O’Donnell, S. W. 2000. Managing foreign subsidiaries: Agents of headquarters, or an interdependent network? Strategic Management Journal, 21(5): 525-548.

Orr, R. J., \& Scott, W. R. 2008. Institutional exceptions on global projects: A process model. Journal of International Business Studies, 39(4): 562-588.

Ouchi, W. 1979. A conceptual framework for the design of organizational control mechanisms. Management Science, 25(9): 833-848.

Ouchi, W. G., \& Maguire, M. A. 1975. Organizational control: Two functions. Administrative Science Quarterly, 20(4): 559-569.

Polanyi, M. 1966. The tacit dimension. Chicago: University of Chicago Press.

Polanyi, M. 1976. Tacit knowledge. In M. Marx \& E Goodson (Eds.), Theories in Contemporary Psychology: 330-344. New York: Macmillan.

Porter, M. 1986. Competing in global industries. Boston: Harvard Business School Press.

Prahalad, C. K., and Doz, Y. L. 1999. The multinational mission: Balancing local demands and global vision. New York: Free Press.

Preacher, K. J., \& Hayes, A. F. 2004. SPSS and SAS procedures for estimating indirect effects in simple mediation models. Behavior Research Methods, Instruments, \& Computers, 36(4), 717-731.

Reiche, B. S. 2011. Knowledge transfer in multinationals: The role of inpatriates' boundary spanning. Human Resource Management, 50(3), 365-389.

Reiche, B. S., Harzing, A. W., \& Kraimer, M. L. 2009. The role of international assignees' social capital in creating inter-unit intellectual capital: A cross-level model. Journal of International Business Studies, 40(3): 509-526.

Rosenkopf, L., A. Nerkar. 2001. Beyond local search: Boundary spanning, exploration, and impact in the optical disk industry. Strategic Management Journal, 22: 287-306. 
Rucker, D. D., Preacher, K. J., Tormala, Z. L., \& Petty, R. E. 2011. Mediation analysis in social psychology: Current practices and new recommendations. Social and Personality Psychology Compass, 5(6), 359-371.

Schulz, M. 2003. Pathways of relevance: Exploring inflows of knowledge into subunits of multinational corporations. Organization Science, 14(4): 440-459.

Schumpeter, J. A. 1934. The theory of economic development. Cambridge, MA: Harvard University Press.

Scott, A. J., \& Holt, D. 1982. The effect of two-stage sampling on ordinary least squares methods. Journal of the American Statistical Association: 848-854.

Shenkar, O. 2001. Cultural distance revisited: Towards a more rigorous conceptualizations and measurement of cultural differences. Journal of International Business Studies, 32(3): $519-535$.

Sheremata, W. A. 2000. Centrifugal and centripetal forces in radical new product development under time pressure. Academy of Management Review, 25(2): 389-408.

Shook, C. L., Ketchen D. J., Jr., Hult, G. T. M., \& Kacmar, K. M. 2004. An assessment of the use of structural equation modeling in strategic management research. Strategic Management Journal, 25(4): 397-404.

Sitkin, S. B., \& Roth, N. L. 1993. Explaining the limited effectiveness of legalistic "remedies" for trust/distrust. Organization Science, 4(3): 367-392.

Skinner, C. J., Holt, D., \& Smith, T. F. (1989). Analysis of complex surveys. John Wiley \& Sons.

Skinner, C., Holt, D., \& Wrigley, N. 1997. The analysis of complex survey data. Hoboken, NJ: John Wiley and Sons.

Snell, S. A. 1992. Control theory in strategic human resource management: The mediating effect of administrative information. Academy of Management Journal, 35(2): 292-327. 
Snell, S. A., \& Youndt, M.A. 1995. Human resource management and firm performance: Testing a contingency model of executive controls. Journal of Management, 21(4): 711-737.

Song, J., Almeida, P., \& Wu, G. 2003. Learning-by-hiring: When is mobility more likely to facilitate interfirm knowledge transfer? Management Science, 49(4), 351-365.

Stroh, L. K., \& Caligiuri, P. M. 1998. Increasing global competitiveness through effective people management. Journal of World Business, 33(1): 1-16.

Studenmund, A. H. (2001). Using econometrics: A practical approach.

Subramaniam, M., \& Venkatraman, N. 2001. Determinants of transnational new product development capability: Testing the influence of transferring and deploying tacit overseas knowledge. Strategic Management Journal, 22(4): 359-378.

Szulanski, G. 1996. Exploring internal stickiness: Impediments to the transfer of best practice within the firm. Strategic Management Journal, 17(SI): 27-43.

Szulanski, G. 2000. The process of knowledge transfer: A diachronic analysis of stickiness. Organizational Behavior and Human Decision Processes, 82(1), 9-27.

Szulanski, G. \& Jensen, R. J. 2006. Presumptive adaptation and the effectiveness of knowledge transfer. Strategic Management Journal, 27(10): 937-957.

Taylor, S., Beechler, S., \& Napier, N. 1996. Toward an integrative model of strategic international human resource management. Academy of Management Review: 959-985.

Teece, D. 2003. Expert talent and the design of (professional services) firms. Industrial and Corporate Change, 12(4): 895-916.

Turner, K. \& Makhija, M. 2006. The role of organizational controls in managing knowledge. Academy of Management Review, 31(1): 197-217.

Tversky, A., \& Kahneman, D. 1973. Availability: A heuristic for judging frequency and probability. Cognitive psychology, 5(2): 207-232. 
Von Nordenflycht, A. 2010. What is a professional service firm? Toward a theory and taxonomy of knowledge-intensive firms. Academy of Management Review, 35(1): 155-174.

Vroom, V. 1995. Work and motivation. San Francisco, CA: Jossey-Bass Publishers.

Winter, S. G., \& Szulanski, G. 2002. Replication of organizational routines. The strategic management of intellectual capital and organizational knowledge: 207-221.

Whittington, K. B., Owen-Smith, J., \& Powell, W. W. 2009. Networks, propinquity, and innovation in knowledge-intensive industries. Administrative Science Quarterly, 54(1): $90-122$.

Yeung, A. K., Ulrich, D. O., Nason, S. W., \& Von Glinow, M. A. 1999. Organizational learning capability: Generating and generalizing ideas with impact. New York: Oxford University Press.

Yli-Renko, H., Autio, E., \& Sapienza, H. J. 2001. Social capital, knowledge acquisition, and knowledge exploitation in young technology based firms. Strategic Management Journal, 22(6): 587-613.

Yu, J., \& Zaheer, S. 2010. Building a process model of local adaptation of practices: A study of Six Sigma implementation in Korean and US firms. Journal of International Business Studies, 41(3): 475-499.

Zander, U. \& Kogut, B. 1995. Knowledge and the speed of the transfer and imitation of organizational capabilities: An empirical test. Organization Science, 6(1): 76-92.

Zellmer-Bruhn, M., \& Gibson, C. 2006. Multinational organization context: Implications for team learning and performance. Academy of Management Journal, 49(3), 501-518.

Zhang, Y., \& Li, H. 2010. Innovation search of new ventures in a technology cluster: The role of ties with service intermediaries. Strategic Management Journal, 31(1): 88-109. 
Figure 1

Ring model of knowledge reach

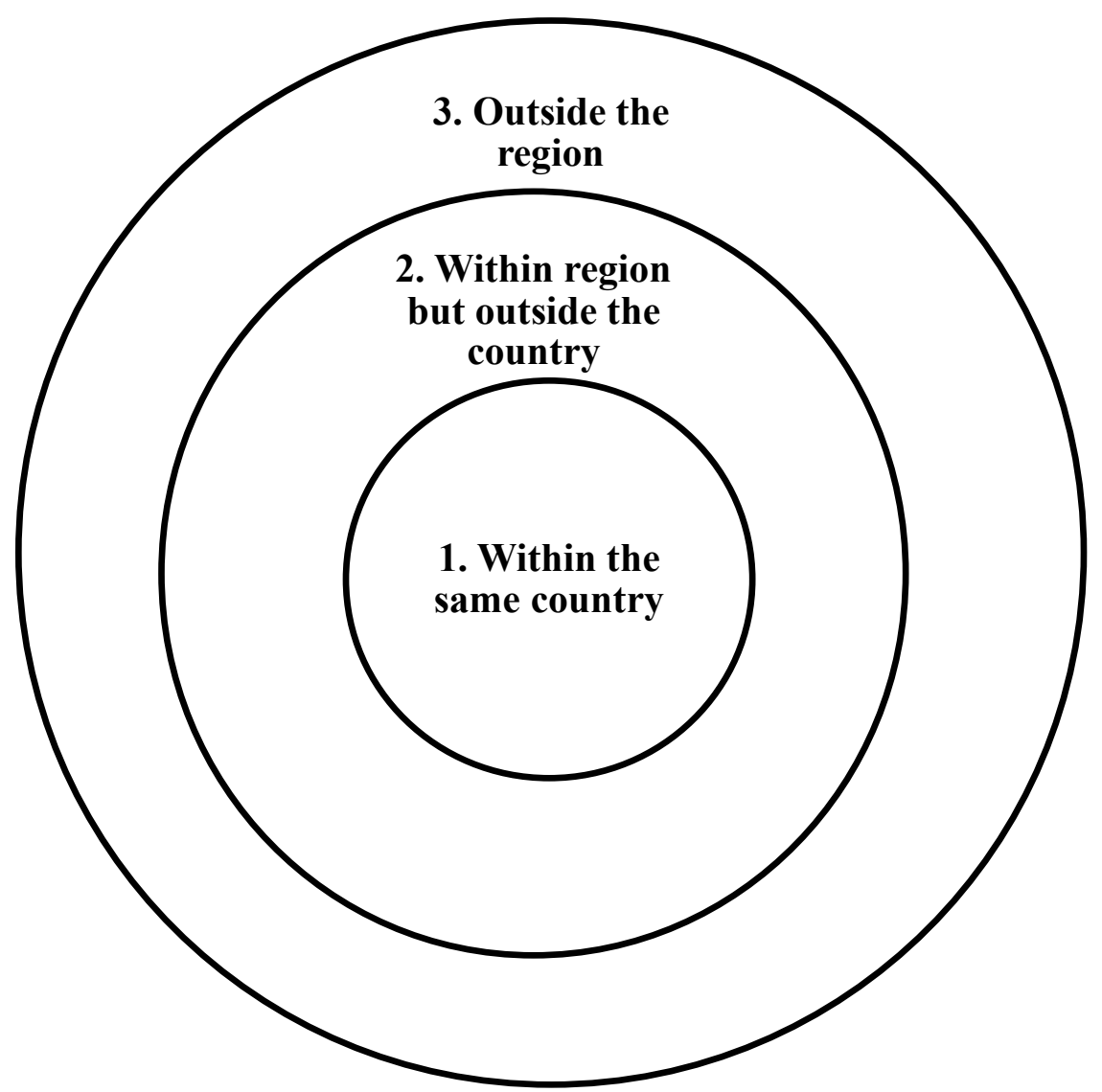

1. Knowledge from within the same country and MNE.

2. Knowledge from outside the country but within the same region and MNE.

3. Knowledge from outside the geographical region but still within the MNE. 
Figure 2

Hypothesized relationships

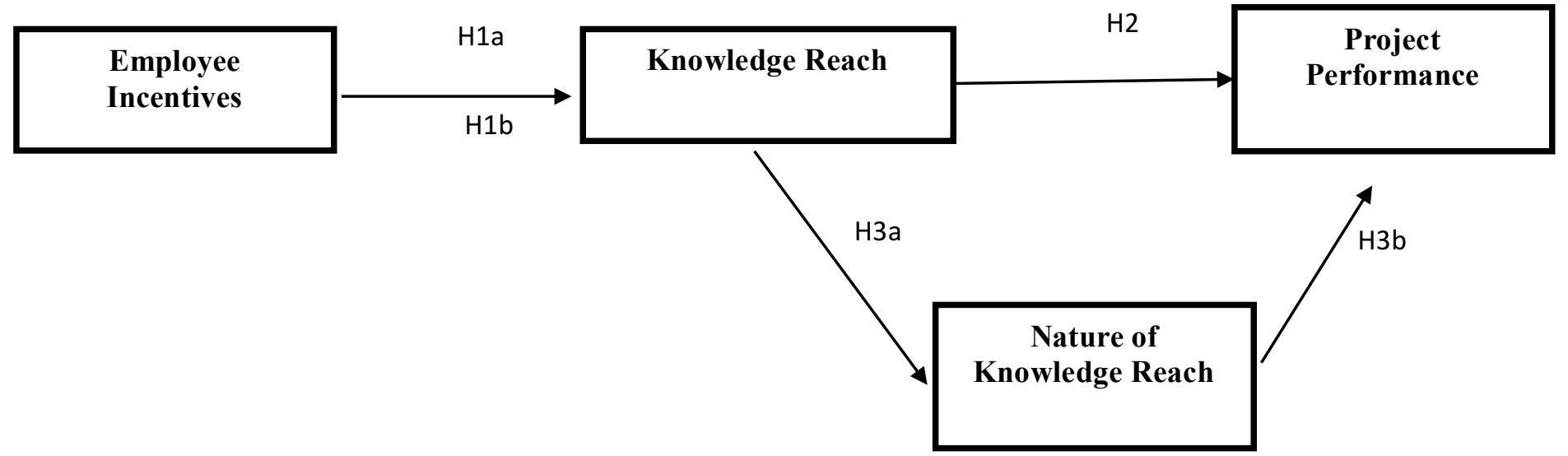


Figure 3

Empirical model of incentives, knowledge reach and performance

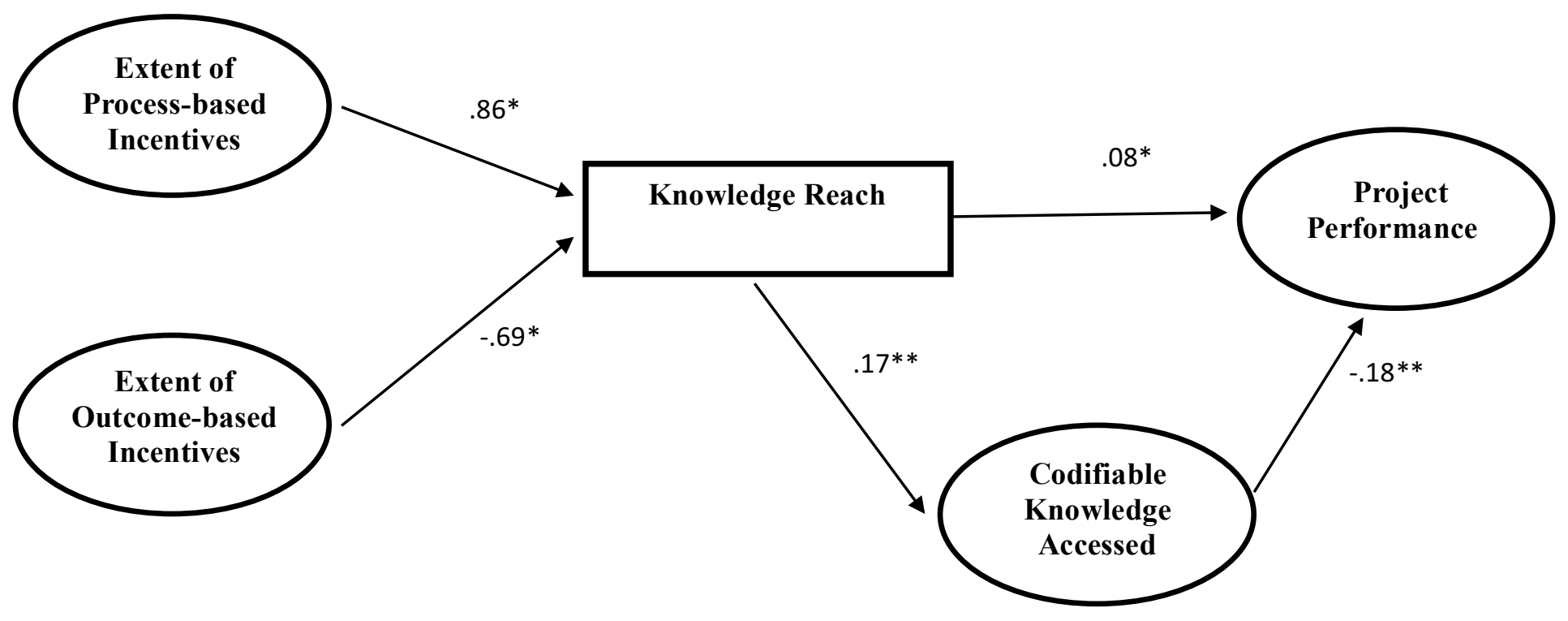

Model Fit: Chi-Square: 1232.59. Degree of freedom: 154.

$\mathrm{CFI}=0.85$ RMSEA: $0.04 .{ }^{*} \mathrm{p}<0.05 .{ }^{*} \mathrm{p}<0.01$ 
Table 1

Countries and completed surveys in database

\begin{tabular}{|c|c|c|c|c|c|}
\hline Country & No. of Surveys & Country & No. of Surveys & Country & No. of Surveys \\
\hline Afghanistan & 2 & Liberia & 2 & Lebanon & 3 \\
\hline Africa Region & 13 & Lithuania & 1 & Lesotho & 1 \\
\hline Albania & 8 & Macedonia & 6 & United States & 23 \\
\hline Algeria & 2 & Madagascar & 3 & Yemen, Republic of & 5 \\
\hline Argentina & 2 & Maldives & 3 & Zambia & 1 \\
\hline Armenia & 2 & Mauritius & 1 & Zimbabwe & 1 \\
\hline Azerbaijan & 5 & Mexico & 4 & West Bank and Gaza & 2 \\
\hline Bangladesh & 14 & Mongolia & 1 & Lao & 3 \\
\hline Belarus & 1 & Montenegro & 3 & Vanuatu & 1 \\
\hline Benin & 1 & Morocco & 2 & Venezuela & 1 \\
\hline Bhutan & 1 & Mozambique & 8 & Vietnam & 9 \\
\hline Bolivia & 4 & Nicaragua & 3 & Yemen, Republic of & 5 \\
\hline Bosnia & 6 & Nigeria & 3 & Jordan & 3 \\
\hline Brazil & 7 & Oman & 1 & Kenya & 12 \\
\hline Bulgaria & 2 & Pakistan & 6 & Uruguay & 1 \\
\hline Burkina Faso & 2 & Papua New Guinea & 1 & Uzbekistan & 1 \\
\hline Cambodia & 7 & Peru & 5 & Indonesia & 21 \\
\hline Cape Verde & 1 & Philippines & 10 & Iraq & 2 \\
\hline Caribbean Region & 1 & Poland & 1 & United Arab Emirates & 1 \\
\hline Central African Republic & 1 & Russian & 10 & India & 11 \\
\hline Central Europe Region & 1 & Samoa & 1 & Ukraine & 5 \\
\hline China & 13 & Saudi Arabia & 1 & Honduras & 2 \\
\hline Colombia & 3 & Serbia & 7 & Uganda & 4 \\
\hline Congo & 1 & Somalia & 1 & Haiti & 1 \\
\hline Egypt & 1 & South Africa & 5 & Tonga & 2 \\
\hline Fiji & 2 & Sri Lanka & 8 & & \\
\hline Ghana & 2 & Tajikistan & 3 & & \\
\hline Guyana & 1 & Tanzania & 3 & & \\
\hline
\end{tabular}


Table 2

Composite reliability and convergent validity of key variables

\begin{tabular}{|lcc|}
\hline \multicolumn{1}{|c}{ Variable } & $\begin{array}{c}\text { Average Variance } \\
\text { Extracted }^{*}\end{array}$ & $\begin{array}{c}\text { Composite } \\
\text { Reliability }^{* * *}\end{array}$ \\
\hline Project performance & 0.57 & 0.90 \\
\hline Outcome-based incentives & 0.67 & 0.89 \\
\hline Process-based incentives & 0.70 & 0.88 \\
\hline $\begin{array}{l}\text { Codifiable internal } \\
\text { knowledge accessed }\end{array}$ & 0.90 & 0.96 \\
\hline $\begin{array}{l}\text { Codifiable external } \\
\text { knowledge accessed }\end{array}$ & 0.86 & 0.95 \\
\hline Use of internal knowledge & 0.81 & 0.94 \\
\hline Use of external knowledge & 0.79 & 0.92 \\
\hline
\end{tabular}

*Average Variance Extracted greater than 0.50 indicates construct validity (Bagozzi \& Yi, 1990)

**Composite reliability greater than 0.70 indicates construct reliability (Hair et al., 1998). 
Table 3

Means, standard deviations, and correlations

\begin{tabular}{|c|c|c|c|c|c|c|c|c|c|c|c|c|c|c|c|c|}
\hline Variable & Mean & S.D. & 1 & 2 & 3 & 4 & 5 & 6 & 7 & 8 & 9 & 10 & 11 & 12 & 13 & 14 \\
\hline $\begin{array}{l}\text { 1. Outcome-based } \\
\text { incentives }\end{array}$ & 2.71 & 0.84 & - & & & & & & & & & & & & & \\
\hline $\begin{array}{l}\text { 2. Process-based } \\
\text { incentives }\end{array}$ & 2.78 & 0.86 & $.73 * *$ & - & & & & & & & & & & & & \\
\hline 3. Knowledge reach & 2.52 & 1.26 & $.19 * *$ & $.15^{*}$ & - & & & & & & & & & & & \\
\hline $\begin{array}{l}\text { 4. Codifiable } \\
\text { internal knowledge } \\
\text { accessed }\end{array}$ & 3.33 & 0.87 & $.37 * *$ & $.41 * *$ & $.24 * *$ & - & & & & & & & & & & \\
\hline $\begin{array}{l}\text { 5. Project } \\
\text { performance }\end{array}$ & 2.96 & 0.68 & .09 & .10 & $.29 * *$ & $.11 *$ & - & & & & & & & & & \\
\hline $\begin{array}{l}\text { 6. Use of internal } \\
\text { knowledge }\end{array}$ & 3.51 & 0.90 & $.34 * *$ & $.38 * *$ & $.30 * *$ & $.57 * *$ & $.25 * *$ & - & & & & & & & & \\
\hline $\begin{array}{l}\text { 7. Use of external } \\
\text { knowledge }\end{array}$ & 3.81 & 0.81 & $.14 *$ & .10 & $.12 *$ & $.19 * *$ & -.03 & .09 & - & & & & & & & \\
\hline $\begin{array}{l}\text { 8. Codifiable } \\
\text { external knowledge } \\
\text { accessed }\end{array}$ & 3.21 & 0.89 & $.29 * *$ & $.26 * *$ & $.24 * *$ & $.59 * *$ & $.25 * *$ & $.27 * *$ & $.44 * *$ & - & & & & & & \\
\hline $\begin{array}{l}\text { 9. Project support } \\
\text { staff }\end{array}$ & 3.78 & 2.92 & .01 & .04 & .06 & .03 & .05 & .01 & .08 & $.12 *$ & - & & & & & \\
\hline 10. Region & 4.51 & 2.17 & .09 & .11 & $.13 *$ & .08 & $.18^{* *}$ & $.13^{*}$ & -.01 & .06 & $.12^{*}$ & - & & & & \\
\hline $\begin{array}{l}\text { 11. Knowledge } \\
\text { accessed from HQ }\end{array}$ & 2.79 & 1.35 & $.17 * *$ & $.13^{*}$ & $.37 * *$ & $.24 * *$ & .14 & $.41 * *$ & .05 & .06 & .09 & .09 & - & & & \\
\hline 12. Cultural distance & 1.37 & 0.98 & -.13 & -.07 & $-.21 *$ & -.15 & -.04 & $-.21 *$ & -.12 & -.04 & -.01 & $-.47 * *$ & -.18 & - & & \\
\hline 13. Expatriate & 0.55 & 0.50 & $-.17 * *$ & -.07 & .04 & -.08 & -.04 & -.04 & $-.12^{*}$ & -.08 & .08 & $.15^{*}$ & .09 & -.06 & - & \\
\hline $\begin{array}{l}\text { 14. International } \\
\text { experiences }\end{array}$ & 3.40 & 2.50 & $-.13 *$ & -.11 & .01 & -.09 & -.03 & .01 & $-.17 * *$ & $-.17 * *$ & .05 & .01 & .01 & $.40 * *$ & .05 & - \\
\hline
\end{tabular}

$*$ Significance at .05 level; $* *$ Significance at .01 level. 
Table 4

Testing of hypothesized relationships in structural equation model

\begin{tabular}{|c|c|c|c|c|c|}
\hline Relationship & Hypothesis & Estimate & S.E. & $\begin{array}{c}\text { Critical } \\
\text { Ratio }\end{array}$ & P-value \\
\hline Process-based incentives to Knowledge reach & H1a & -.69 & .32 & -2.16 & .03 \\
\hline Outcome-based incentives to Knowledge reach & $\mathrm{H} 1 \mathrm{~b}$ & .86 & .36 & 2.41 & .02 \\
\hline Knowledge reach to Project performance & $\mathrm{H} 2$ & .08 & .04 & 1.96 & .05 \\
\hline Knowledge reach to Codifiable knowledge accessed & $\mathrm{H} 3 \mathrm{a}$ & .17 & .04 & 4.07 & .00 \\
\hline Codifiable knowledge accessed to Project performance & $\mathrm{H} 3 \mathrm{~b}$ & -.18 & .05 & -3.50 & .00 \\
\hline Use of internal knowledge & Control & .13 & .06 & 2.29 & .02 \\
\hline Use of external knowledge & Control & -.16 & .07 & -2.19 & .03 \\
\hline Codifiability of ext. knowledge accessed & Control & .24 & .08 & 3.14 & .01 \\
\hline Project support staff & Control & .01 & .01 & .25 & .80 \\
\hline Knowledge accessed from HQ & Control & -.01 & .03 & -.39 & .70 \\
\hline Middle East and North Africa Region & Control & -.24 & .18 & -1.33 & .18 \\
\hline Latin America and Caribbean Region & Control & .04 & .19 & .20 & .83 \\
\hline East Asia and Pacific Region & Control & -.07 & .19 & -.34 & .74 \\
\hline South Asia Region & Control & -.12 & .19 & -.62 & .53 \\
\hline Southern Europe and Central Asia Region & Control & .09 & .19 & .47 & .64 \\
\hline Sub-Saharan Africa Region & Control & -.05 & .17 & -.26 & .80 \\
\hline Headquarters & Control & .43 & .21 & 1.99 & .05 \\
\hline Expatriate & Control & .21 & .13 & 1.58 & .12 \\
\hline International experience & Control & .01 & .03 & .23 & .82 \\
\hline Fit Statistics & \multicolumn{2}{|c|}{$\begin{array}{c}\text { Chi-square }=1232.59 \\
\text { RMSEA }=0.04\end{array}$} & \multicolumn{3}{|c|}{$\begin{array}{c}\text { Degree of freedom }=511 \\
\text { CFI }=0.85\end{array}$} \\
\hline
\end{tabular}

